\title{
ATMOSPHERES OF LIBERTY: RUSKIN IN THE CLOUDS
}

\author{
BY DANIEL WILLIAMS
}

John Ruskin lamented his culture's inattention to the "quiet and subdued passages of unobtrusive majesty" passing daily across the sky. ${ }^{1}$ In a harangue that might hold good today, he asks in Modern Painters I (1843): "Who . . . can tell me of the forms and the precipices of the chain of tall white mountains that girded the horizon at noon yesterday? Who saw the narrow sunbeam that came out of the south and smote upon their summits until they melted and mouldered away in a dust of blue rain?" (3:344-45). ${ }^{2}$ In his own time, at least, someone was paying attention:

up above, what wind-walks! what lovely behaviour

Of sílk-sack clóuds! has wilder, wilful-wávier

Méal-drift moulded ever and melted acróss skíes?3

Adapting Ruskin's terms in a conscious and enthusiastic response, Gerard Manley Hopkins looks to the sky in undiluted joy, expressing in his customary pied figures both the majesty of clouds and his breathless communion with them. One detail brings out a characteristic of clouds at the heart of Ruskin's theory and aesthetics of the atmosphere. In yoking volition and vagary into a single thought, the curious comparative "wilful-wávier" condenses the aspect under which clouds seem enviably at liberty to direct their own movements even as they are merely buffeted by governing winds. Clouds are at once images of freedom and reminders of unfreedom.

Ruskin's cloud studies, I argue, encompass an inquiry into the character of human liberty, in a sustained fashion in Modern Painters and episodically throughout his long career. Ruskin often has recourse to figures of freedom and government in the clouds, and it is within their ambit that he moderates his lifelong aversion to liberty as a concept and cultural mode. Initially dismissing liberty outright as a liberal indulgence, Ruskin reconciles himself to a dynamic model in which freedom and constraint are coupled. The first two sections of this essay demonstrate how Ruskin's lengthy engagement with clouds in Modern Painters constitutes a discovery of the problem of cloud 
agency, and a subsequent revision of this view whereby clouds retain liberty only through measures of self-government. A self-confessed "cloud-worshipper," Ruskin modifies and complicates his views-while still retaining a figurative emphasis on liberty and social order-through later genres of cloud study, including his practical and historical lectures, his mythical study of Greek sky myths, and his late blend of meteorological portent and moral screed directed at what he termed the storm-cloud (6:75). The third section argues that attending to Ruskin's figurative dynamic between freedom and restraint in the clouds gives some coherence to his wider, incompatible statements about liberty. I consider his critique of artistic license in the return to Modern Painters (1856) in its middle volumes, following an intervening shift to historically inflected writing in The Seven Lamps of Architecture (1849) and The Stones of Venice (1851-53), where artistic obedience is set against the free, unmechanized hand of the Gothic craftsman, as well as later lectures that critique liberty in various guises. Tensely poised between liberalism, republicanism, and authoritarian conservatism, Ruskin's tempered version of liberty-which I follow him in naming libertas - cannot finally be subsumed under one conceptual framework. His account's paradoxes remain operative precisely because he situates them in changing natural entities, laboring to see in these intuitively available forms not a fixed concept but a fluid model of freedom-a fragile harmony where liberty is not a static right but a shifting and hard-won virtue, to be earned and protected.

This essay renovates Ruskin in several ways, not least from lingering misconceptions about his politics. By repurposing the figurative elements of Ruskin's aesthetic criticism within a political framework, I suggest that inconsistencies across his art historical œuvre become comprehensible as stages in a developing account of liberty. I identify a deeper rationale for his generic affiliation to realism and the "science of Aspects" (3:347), in his elevation of J. M. W. Turner's "true" (3:409) skies over the fluffy falsehoods and "pillowy organization" (3:375) of other artists, and revise criticism of his cloud aesthetics as dreamily exempt from broader concerns. ${ }^{4}$ Conversely, by reading Ruskin's political writings for their recurrent figures, I underline the complex ways in which political thinking sometimes emerges through an aesthetic mode, without necessarily treating the aesthetic as an ideological optic. This essay thus contributes to recent work by scholars such as Linda Dowling, Judith Stoddart, David Thomas, and Caroline Levine, who hold a more intricate view of the seam joining Victorian aesthetics and politics and reclaim Ruskin from a shallow characterization as one 
among many "destroyers of liberalism." I seek to revivify connections between criticism on Ruskin's aesthetics, which often notices his social analogies without pursuing them in detail, and writing on his social and political theories, which likewise instances aesthetic (typically architectural) writing in somewhat general and theoretical terms. ${ }^{6}$ By considering how Ruskin's shifting political affiliations and evolving aesthetic opinions can productively be thought together, these diverse lines of inquiry come into sustained contact. More broadly, I participate in a mode of recent Romantic criticism-by scholars such as Mary Favret, Mary Jacobus, and Marjorie Levinson - that reads atmospheric phenomena, and clouds in particular, as suggestive models for a variety of concerns. Whether they typify the mediated, affective experience of wartime; the confluence of materiality and immateriality in lyric poetry; or a vision of distributed individuality imagined as a mode of "being numerous," clouds have come to function as both figure and model for a newly ambient historicism. ${ }^{7}$ Reframing Ruskin within these contexts, consolidating his scattered assertions about liberty into a more substantive account than formerly available, and returning to his social statements in conjunction with his cloud aesthetics, I recast him as a compelling theorist of liberty who restores intuitive and aesthetic facets to politics.

\section{I. "EVERY WREATH OF WRITHING VAPOUR": CLOUD AGENCY}

Ruskin believes that clouds were brought into being to provide for our protection and instruction. Although created by the divinity and partaking of its substance, they share also in ours. He commences his discussion in Modern Painters by declaring the sky to be "almost human in its passions, almost spiritual in its tenderness, almost divine in its infinity" (3:344), and in the last volume still views the clouds as a zone of "intermediate being" tasked to "sign the changeless motion of the heavens with a semblance of human vicissitude" (7:133). In looking up at the remote infinity of blue we find comfort in the "flying vapour" (7:133) that is analogous to our "dewy existence" (4:139), in a phrase borrowed from Aristophanes's comedy The Clouds. This interpenetration of theme persists in Ruskin's figurative register, where the form, arrangement, and movement of clouds mime human institutions of liberty and government, in the shadow of obedience to larger forces and to God. ${ }^{8}$ Such analogical models have their precedent in Romantic topoi, such as the organic polis envisioned by Tory radicals like Samuel Taylor Coleridge and Thomas Carlyle, and implied in the confluence 
of natural figures and political concerns of William Wordsworth's "Ode to Duty" (1807), his sequential "Sonnets to Liberty" (1807, 1815), and The Excursion (1814). Ruskin's modulation of this inheritance is distinctive and complex. ${ }^{9}$ In this section, I demonstrate how his blended figures lead him to a troubling discovery-the apparent agency of clouds - that he attempts to circumscribe by outlining a dynamic between internal volition and external control, setting cloud shape and movement against the invisible conditions of wind, temperature, and altitude. This dynamic necessarily alters across different cloud types, although Ruskin expresses a marked aesthetic and moral preference for what might be termed self-governing clouds, those whose austere harmony willingly subjects internal to external agency.

Outlining three hierarchical regions of cloud formation, Ruskin partly adopts his terms from those first introduced in 1802 by the English scientist Luke Howard, but departs from that classification scheme for reasons not grounded in meteorology. ${ }^{10}$ Where the upper region (cirrus) is explained almost entirely through its subjection to external system, the unruliness of the middle region (cumulus, stratus) prompts reflections on the constitutive agency of clouds in relation to the wind that forms and carries them, an account that continues to the lower region (nimbus), where clouds are seen not in thrall to external agency but as bearing the wind as part of their own structure and selfdirection. ${ }^{11}$ Ruskin commences the section "Of Truth of Clouds" at the zenith, with cirrus clouds. These apparently "motionless multitudinous lines of delicate vapour" are summarized according to a number of general traits, being symmetric, clean-edged, exceedingly numerous, various in their patterns, and pure in color (3:359). Cirri have a "narrow extremity . . . invariably turned to the wind, and the fibres are parallel with its direction," such that their very form embodies subjugation to external pressures (3:360). In this they differ from others, which,

though there are certain laws which they cannot break, have yet perfect
freedom from anything like a relative and general system of government.
The upper clouds are to the lower, what soldiers on parade are to a
mixed multitude: no men walk on their heads or their hands, and so
there are certain laws which no clouds violate; but there is nothing,
except in the upper clouds, resembling symmetrical discipline. (3:360)

Extending the military figure, Ruskin notes that these clouds are at the mercy of the "violence of the wind" (3:361), and presses the comparison, speaking of cirri as "all governed by the same forces and falling into one general form" (3:362). He provides an impressionistic but unscientific 
explanation for their manifest diversity as part of an overall system, for "nature never lets one of the members of even her most disciplined groups of cloud be like another" (3:362). This most perfect obedience of cirri, more than once described as the resplendent soldiers of the heavens, paradoxically yields their singularity of form. Of thousands of instances, Ruskin notes, each seems to have its "separate beauty and character," and in contrast to the heftier motions of the lower clouds, they rest on high in "elevation" and "repose" (3:362). Cirri are at once the most numerous and the most individuated clouds, appearing as both dutiful flocks and ranged battalions_or, in a Wordsworthian idiom, as alternately "crowd" and "host." 12 Ruskin's admiration for cirri dovetails with his aesthetic lionization of Turner, the singular master of depicting them across the volumes of Modern Painters, in contrast to previous artists and schools (3:363-69; 7:156-57). Their pliant subjection is such that the wind's governing violence drops from view, appearing not to exert any pressure in ushering them along. Hence Ruskin adapts these lines from Percy Bysshe Shelley's Prometheus Unbound (1820) to capture the form:

Underneath the young grey dawn

A multitude of dense, white, fleecy clouds

Were wandering in thick flocks along the mountains,

Shepherded by the slow, unwilling wind..$^{13}$

The "unwilling wind" marks out these clouds as cirri and exemplifies the placid function of the shepherd - a motif both classical and scriptural-in governing the fact and direction of movement. The strictures of external government have been so thoroughly internalized as to make the wind seem passive and peripheral, when in truth its will is operative in their every rank and file.

When Ruskin turns away from the clouds that draw his fervent praise, those less articulated clouds of the middle region-the stratus and cumulus families - hardly pass muster. They are "white, ragged, irregular, and scattered vapour," collecting in forms "partially rounded, clumsy, and ponderous" (3:370). Speaking of the lower cumuli, Ruskin finds volition a powerful element in the form, noting that the "result of this arrangement in masses more or less angular, varied with, and chiefly constructed of, curves of the utmost freedom and beauty, is that appearance of exhaustless and fantastic energy which gives each cloud a marked character of its own" (3:373). The accent on distinctive character modulates into an assumption of agency, so that the general outline of cumulus is "full of character and decision" (3:373). When 
depicted by Turner, cumulus clouds can seem to be "unaffected by wind," changing shape on account of their own "elastic force" and "inward energy," as though their frantic metamorphoses were expressions of an inner will (3:386).

The jagged vagaries of the middle region compel a marked shift of emphasis in Ruskin's explanatory mode. Where he had exempted cirri from such concerns, he now turns to empirical explanation in an attempt to account for the shape-shifting dynamics of cumuli, defining all clouds as "vapour rendered locally visible by a fall of temperature" (3:371).${ }^{14}$ Tacitly leaning on the theories of the Swiss natural historian Horace-Bénédict de Saussure and his Voyages dans les Alpes (1779-96), Ruskin offers an explanation of how helm clouds-those that hover above summits-form, espousing the theory that clouds follow a "law of formation ... being bounded rather by lines expressive of changes of temperature in the atmosphere, than by the impulses of the currents of wind in which those changes take place" (3:373). ${ }^{15}$ By describing clouds as the shifting, visible manifestations of temperature gradients, Ruskin effectively renounces the agency he otherwise reads into their forms. He refashions the evident and energetic volition of cumuli as a function of the temperature and wind system, and rebrands their singular characters as mere exemplars of a general and invisible rule.

Such a recalibration of cloud agency cannot, it seems, serve any explanatory function in the lower region of clouds, where rain and storm dictate their own movements. This is vividly expressed in Turner's rendering of Long Ship's Lighthouse (Figure 1), where the roiling movements of cloud and spray constitute one unbroken, energetic system, fracturing the horizon line and encompassing all possible directions of movement in the picture plane. ${ }^{16}$ So frenzied is the movement of rain-clouds that Ruskin sees them personified as a mass of aggregated wills. The rain-cloud is "not formless, but full of indications of character, wild, irregular, shattered, and indefinite; full of the energy of storm, fiery in haste, and yet flinging back out of its motion the fitful swirls of bounding drift, of tortured vapour tossed up like men's hands, as in defiance of the tempest" (3:404). In images evocative of social upheaval, he wonders at the "independent passion, the tumultuous separate existence, of every wreath of writhing vapour, yet swept away and overpowered by one omnipotence of storm" (3:404-5). This oppressive overallness of storm-clouds often marks the images Ruskin adduces to illustrate them, as in Turner's view of Stonehenge (Figure 2), where jagged lines of light edging the clouds at once mimic and overpower their architectural counterparts on the 


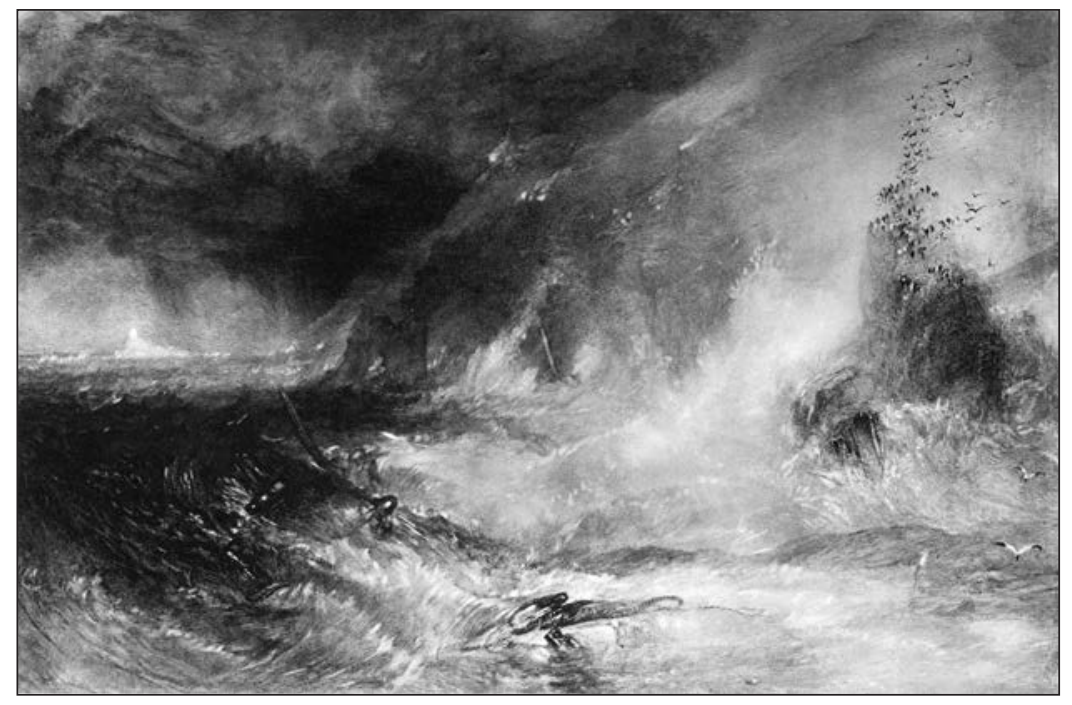

Figure 1. J. M. W. Turner, The Long Ship's Lighthouse, Land's End. From Turner \& Ruskin, 2 vol., ed. Frederick Wedmore (London: George Allen, 1900), facing 2:220. Nor 900, Houghton Library, Harvard University.

ground, as the creaturely world — a lifeless shepherd, his distraught dog, and his cowed sheep-lies helpless before the uncontrollable flocks above.

The collective storm stands in for the external power of the winds, as Ruskin describes them in Turner's drawing of Coventry (Figure 3), where the sweeping shadow lines visible across Stonehenge dominate not an archaic temple but an industrializing town, with similarly chaotic effects. Ruskin observes that, in this image, "there is not one cloud that repeats another, nor one curve in itself monotonous, or without character, and yet every part and portion of the cloud is rigidly subjected to the same forward, fierce, inevitable influence of storm" (3:406). The turbulent energies of rain-clouds represent an overthrow of external forces by an internal order of will and self-government, in contrast to the docile cirri. Although "subject to the same great laws of form" (3:394), Ruskin argues, rain-clouds are nonetheless "not solid bodies borne about with the wind, but they carry the wind with them, and cause it" (3:395, emphasis added).

At this early stage of Modern Painters, in an account shot through with contradictory impulses and upended causation, Ruskin declares the "eternal principles of the heavens" as "fitfulness and infinity" (3:381). 


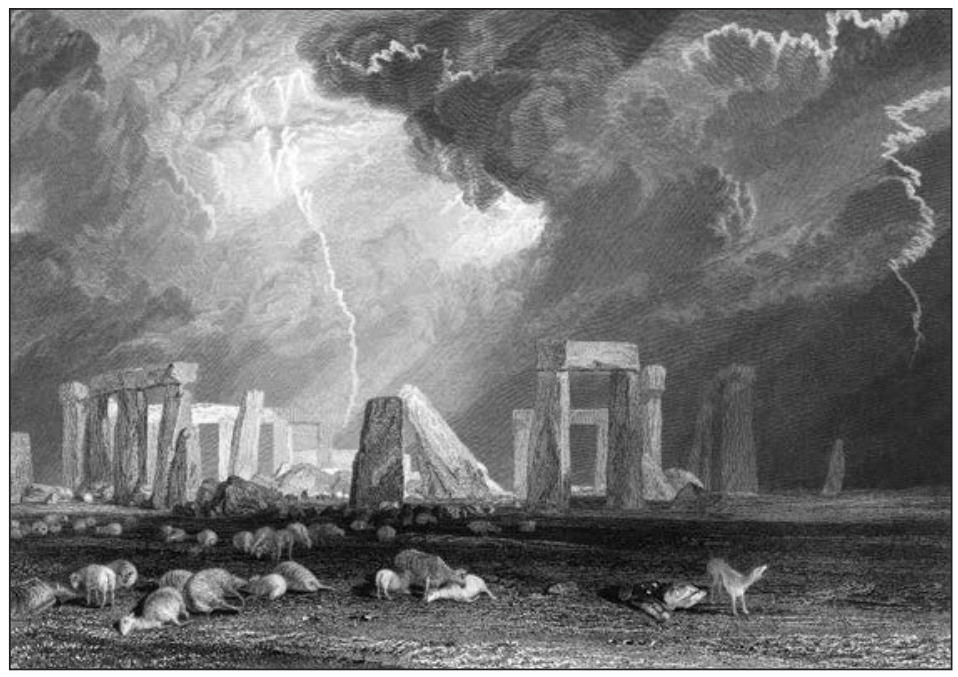

Figure 2. J. M. W. Turner, Stone Henge, engraved by Robert Wallis. From Picturesque Views in England and Wales, 2 vol. (London: Longman, Orme, Brown, Green, and Longmans, 1838), vol. 1: "All its forms are marked with violent angles, as if the whole muscular energy ... of the cloud were writhing in every fold" (3:413). Typ 805.38.8530, Houghton Library, Harvard University.

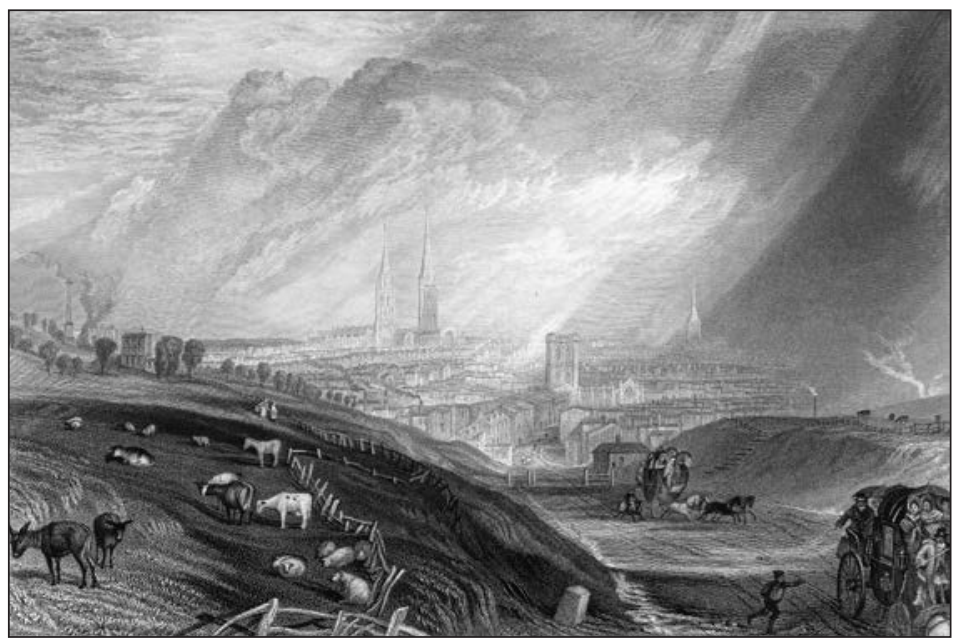

Figure 3. J. M. W. Turner, Coventry, engraved by Samuel Fisher. From Picturesque Views in England and Wales, vol. 2 (1838). Typ 805.38.8530, Houghton Library, Harvard University. 
Yet he struggles with the former quality, acknowledging the freedom of clouds and then denying their "fitfulness," emphasizing instead their subjugation to global forces. Where cirrus clouds obediently internalize the restraints imposed on them, stratus and cumulus clouds attempt to subvert them. Rain-clouds display a wild agency that overtakes and absorbs the external storm that purportedly controls their movement.

\section{II. "DEEP AND SOFT CONSENT": SELF-GOVERNMENT IN THE CLOUDS}

I have been highlighting the language of liberty and government in the skies and their representations, but Ruskin's remarks must still be seen under the presiding rubric of his early work: accurate analysis and observation; phenomenological realism in artistic representations; truth as a "science of Aspects" (3:347). What he trenchantly calls the "falsehoods" (3:375) committed by most painters other than Turner amount to "depriving heaven of its space, clouds of their buoyancy, winds of their motion, and distance of its blue" (3:378). Yet despite the title "Of Truth of Clouds" and the orderly presentation of cloud regions, forms, and movements, Ruskin's early work relies on a tacit figurative register. In the last volume of Modern Painters, he appeals to a more explicit range of figures in order to shape a discussion that takes somewhat more notice of scientific explanation, and integrates the political morality developed in his intervening writings on architecture. ${ }^{17}$ In considering the section "Of Cloud Beauty," I show how Ruskin's updated account, along with its baroque overhaul in figurative language, retains in striking fashion the earlier emphasis on liberty but revises the arrangements so that clouds more explicitly incorporate measures of government and restraint. ${ }^{18}$

Ruskin's scriptural and allegorical frame is restated in the return to Modern Painters in 1856, where the detailed investigation of Turner begins and he briefly considers the sky in order to frame an analysis of landscape. Interpreting the creation account of Genesis, Ruskin argues that clouds are the result of the division of waters, locating God's abode more properly in the proximate "clouds" than in the distant "heavens," so that the deity takes on the "veil of our human thoughts" (6:110). When reframing his cloud inquiry in the final volume, Ruskin keeps the scriptural frame, underlining his period's real uncertainty as to how clouds float in the atmosphere: "Knowest thou the balancings of the clouds?" (Job 37:16 quoted on 7:135) ${ }^{19}$ Ruskin now emphasizes the buoyancy of clouds and embraces the theory that they are composed of 
millions of "hollow spherical globules" each with an "enclosed vacuity," the balance between internal and external densities allowing them to float $(7: 137)$. This vesicular theory of cloud formation had been current in the eighteenth century but was falling out of favor in Ruskin's time, although it was still related to a tentative explanation of the sky's color, as he seems to acknowledge (7:139-40).$^{20}$ Later, Ruskin would take note of a correction by the young physicist Oliver Lodge, with whom he pursued a jejune correspondence on atmospheric science. ${ }^{21}$ An 1884 Postscript appended to Modern Painters oddly retrofits his text, calling into question the notion that clouds float, whether in spheres or droplets of vapor, while retaining the figure of "cloud-balancings" $(7: 141-43) .{ }^{22}$

This revised empirical account of the formation and structure of clouds — as hollow, floating spheres—does little to avoid the problems of cloud movement and agency. In returning to restraint and "limitation," Ruskin inflects empirical exposition with moral figures and claims (7:140). He presents the difficulty in summary form:

all these questions respecting substance, and aspect, and shape, and line, and division, are involved with others as inscrutable, concerning action. The curves in which clouds move are unknown;- - nay, the very method of their motion, or apparent motion, how far it is by change of place, how far by appearance in one place and vanishing from another. (7:140)

Since the "vapour" of clouds "floats in and with the wind," the earlier explanation in terms of clear demarcations and temperature gradients now appears to overstate the case (7:144). Ruskin thus restores an even balance between cloud agency and the shaping winds. In this reclassification, he abandons the altitudinal hierarchy of regions for a taxonomy that makes morphology its presiding rule, speaking of "massive" and "striated" cloud forms, which can variously describe the manifestations of clouds in the three regions (7:144). In Ruskin's drawing of the evening sky above Beauvais (Figure 4), distinct morphologies, marked out through chiaroscuro, cross the levels of Ruskin's prior altitudinal classification: cirri in patches, flocks, and lines occupy the top half, blending below with cumuli and "fragments of true rain-cloud . . . governed by curves of their own" (7:154).

Ruskin notes, moreover, that these categories are dependent on the clouds themselves rather than on the wind, for the "strongest wind will not throw a cloud, massive by nature, into the linear form" (7:145). This is a clear revision of his earlier account and doubles as 


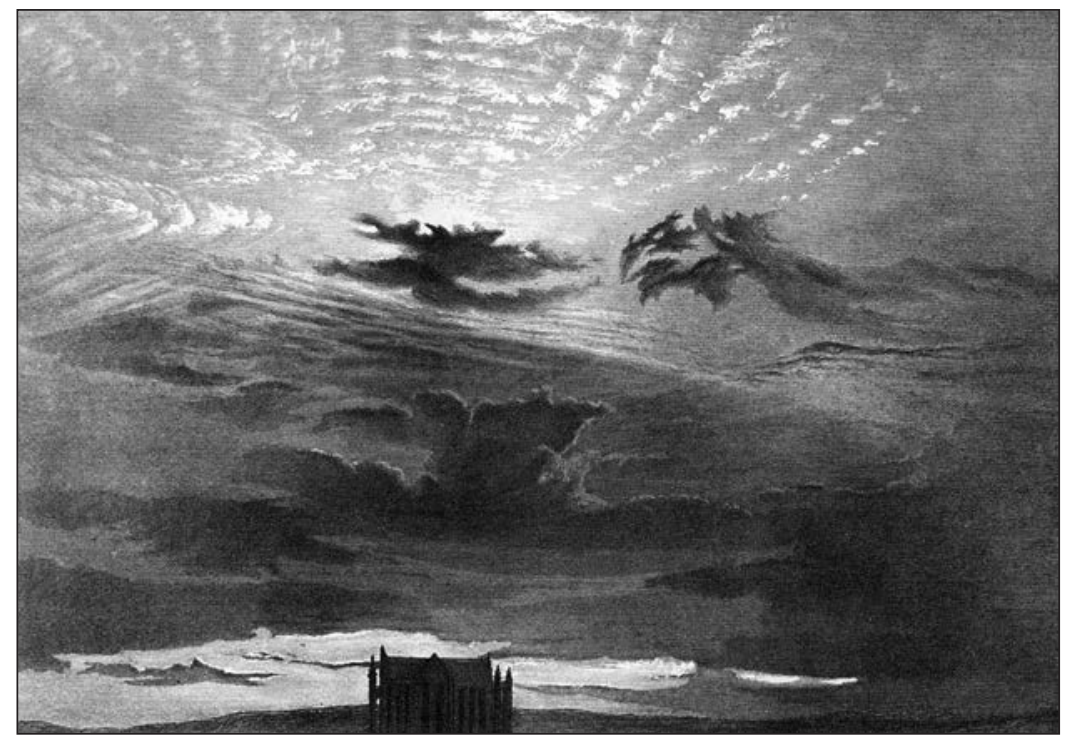

Figure 4. John Ruskin, Light in the West Beauvais. From Modern Painters V (1860), facing 7:154. Harvard College Library, Widener Library, Widener 21411.7, vol 7.

an allusion to the practical difficulties of cloud representation. Since they "combine visibility and volume without surface," all clouds to some extent resist linear capture in drawing and "oppose line." ${ }^{23}$ They are best rendered, Ruskin feels, not by the "uncloudlike" pen but by the softness of pencil or brush (7:150n). If clouds are broadly to be seen as restrained in the sense that their movements are determined by wind, in form they nevertheless retain the freedom to have certain internal characters and arrangements, which only a disciplined representational touch can capture.

Alluding to his earlier citation of Shelley, Ruskin selects "cloudflocks" as his new term for cirri, the clouds exhibiting "quietness and multitude," even though his images of them (Figures 4 and 5) do not attempt to capture their numerical array but only singular, disaggregated, and highly stylized instances of the form (7:146). Ruskin thus tacitly adumbrates, in visual form, his changed thinking about cirri as individually self-governing entities, rather than groups merely subjected to a system of external control.

In trying to explain how cirrus formations, in astonishing numbers, come to be composed in orderly lines with "perfect harmony among 


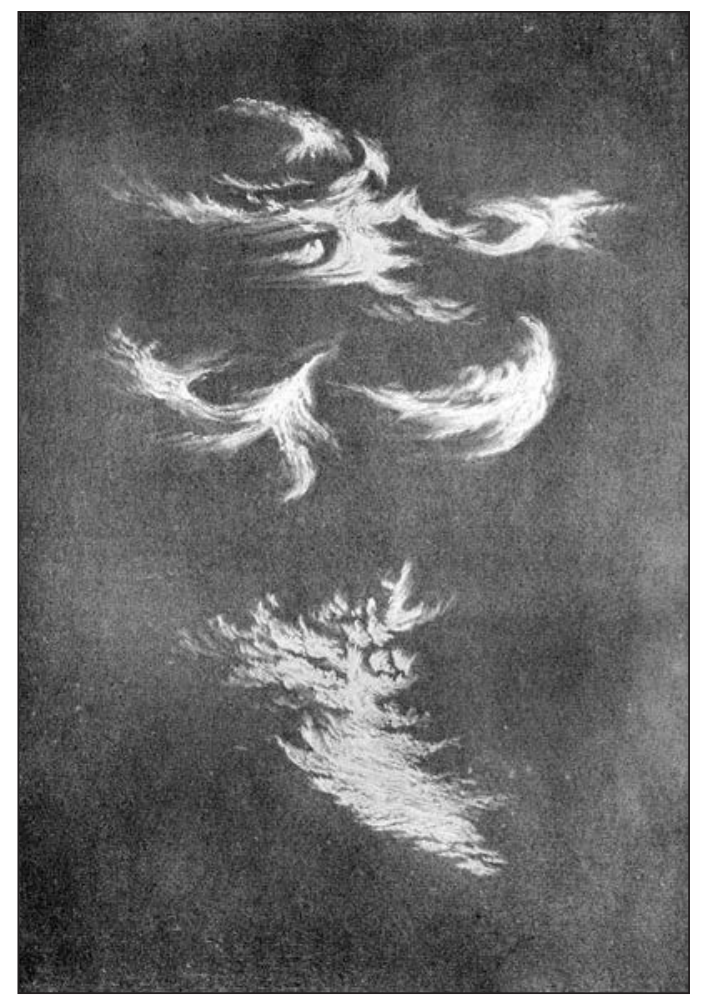

Figure 5. John Ruskin, The Cloud-Flocks. From Modern Painters V (1860), facing 7:147. Harvard College Library, Widener Library, Widener 21411.7, vol 7.

the curves," Ruskin now dispels the external cause of wind as a satisfactory explanation, and adverts to a recurrent figure in his lexicon of liberty (7:149). "If you throw dust that will float on the surface of a slow river," he writes, "it will arrange itself in lines somewhat like these" (7:150). This description keeps movement and mutability moored to a unifying restraint, for thousands of clouds are "all obedient to one ruling law, gone forth through their companies; - each marshalled to their white standards, in great unity of warlike march, unarrested, unconfused" (7:150). Yet in recalling the military figure deployed in his earlier account, Ruskin here changes the outcome by making cirrus an emergent phenomenon. He notes that we have "difficulty in accounting satisfactorily for the individual forces which regulate the similar shape of each mass, while all are moved by a general force that 
has apparently no influence on the divided structure" (7:151). The banks of a river may dictate general restrictions on the flow of water, as the wind does for the global form and movement of clouds, but such external constraints have a diminished causal influence on internal structure - the particles of dust, the lines of cirri. The thoroughgoing passivity of cirri now appears as a self-enforced obedience, allowing for formal freedom within the parameters of restraint.

A similarly subtle recalibration occurs in accounting for cumuli. Ruskin continues to define them as "windless" but seems equivocal on how their "solemn, continuous, inexplicable" movements are governed, since their "steady advance or retiring" is either "animated by an inner will, or compelled by an unseen power" (7:162, emphasis added). In the earlier volume the discovery of volition seemed almost to compel a qualifying account, which styled the clouds as mere effects of temperature contours rather than as agents. Ruskin here admits defeat, finding that he can neither draw nor sufficiently explain cumulus formations, but his terms are more favorable. He highlights their agency as well as his wondering incomprehension in respect of these "positive, fantastic, defiant, determined" forms, now called "cloud-chariots" after Psalm $104(7: 163)$.

In closing out the section on rain-clouds (Figure 6) — which emphasizes the Greek sky myths taken up in subsequent work-Ruskin makes his changed views the subject of an explanatory apology about the lack of "pleasure and freedom" in his accounts of beauty (7:193). He imagines a putative reader of his work who "thought that it would lead him at once into the fields of fond imagination, and may have been surprised to find that the following of beauty brought him always under a sterner domination of mysterious law; that brightness was continually based upon obedience, and all majesty only another form of submission" (7:193). Ruskin has been insisting on the "severities" of beauty-which he claims is not "a pleasure to be snatched, but a law to be learned" - and he reminds us of his earlier thought that beauty's "modes of appeal present constant types of human obedience to the Divine law" (7:193). He further notes that, of all the purposes served by art, "none are higher than its setting forth, by a visible and enduring image, the nature of all true authority and freedom;--Authority which defines and directs the action of benevolent law; and Freedom which consists in deep and soft consent of individual helpfulness" (7:229). In a note, he points to John Stuart Mill's recently published On Liberty (1859), glossing "individual" as "distinct and separate in character, though joined in purpose" (7:229n). Ruskin thus highlights 


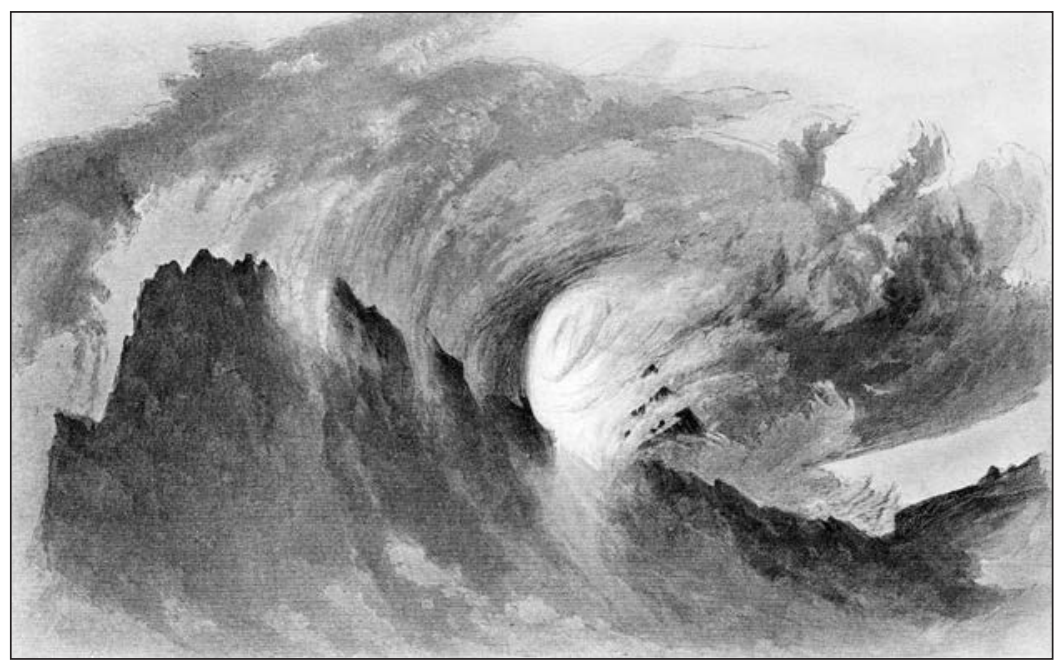

Figure 6. John Ruskin, "Venga Medusa." From Modern Painters V (1860), facing 7:168. Harvard College Library, Widener Library, Widener 21411.7, vol 7. Ruskin calls this "the most terrible . . . highest storm-cloud" (7:184).

the interaction between independent power ("distinct and separate") and the uniting force of external government ("joined in purpose") that has come to occupy his descriptions of clouds, which seem implied in the strange image of "deep and soft consent."

I have been claiming that Ruskin recasts his figurative register to generate an original account of the relational harmony that balances external constraint and internal volition or agency. Across Modern Painters, cirrus clouds acquire a measure of liberty in their selfgoverning form, although general forces still dictate their movements; stratus and cumulus clouds no longer surrender their restive agency to temperature gradients and the freedom Ruskin accords them seems noble rather than undisciplined; and rain-clouds find their wild self-government characterized in relation to a system where austere but benevolent restraint is standard. This heightened insistence on the character of restraint does not, I believe, distract from the sense that the later volume also amplifies the liberty of clouds. One image might serve to encapsulate the apparent paradox. Earlier Ruskin had explained helm clouds by adverting to a combination of wind patterns and temperature gradients. He now recalls that helm clouds occur as often on hot mountain summits as in cool Alpine regions, and so 


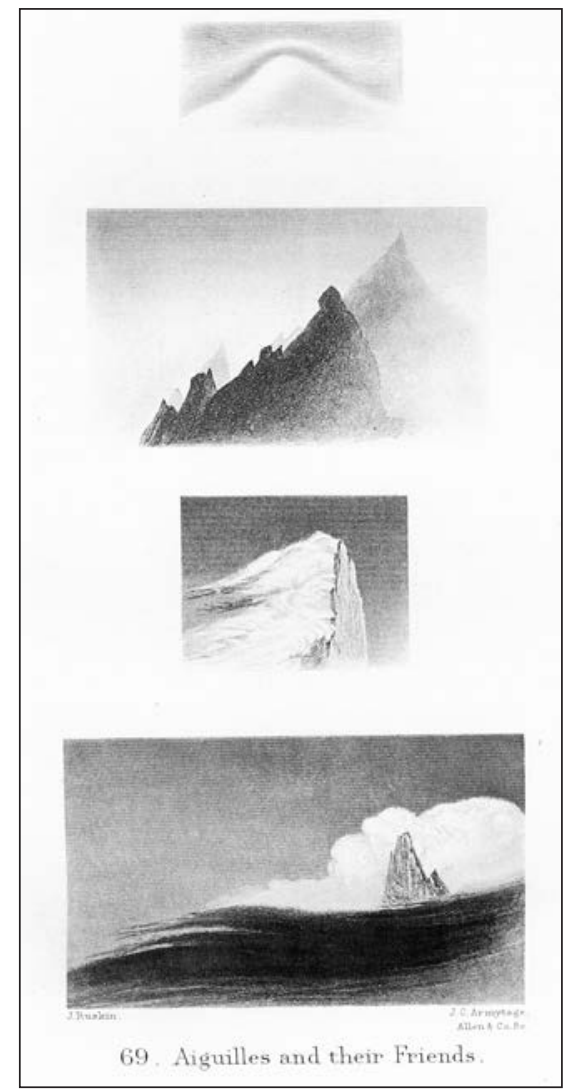

Figure 7. John Ruskin, Aiguilles and their Friends. From Modern Painters V (1860), facing 7:166. Harvard College Library, Widener Library, Widener 21411.7, vol 7.

maintains the earlier account only for the special case of clouds forming under the lee of mountain peaks (that is, away from direct winds) (7:164). He offers quasi-empirical images of wind patterns (Figure 7) that seem visually to confirm the hypothesis, but registers perplexity at helm clouds generally $(7: 164-67) .{ }^{24}$

Ruskin offers the example of Mount Pilatus in Switzerland, noting the fanciful etymology whereby the mountain's name and its associated cloud came to be termed pileatus, a dubious conflation of Pilatus with the Latin pileus, a felt cap given to slaves upon manumission, hence a "cap of liberty," which Ruskin deprecates -in a characteristic barb at revolutionary events in Europe a decade earlier — as "stormy cloud 
enough sometimes on men's brows as well as on mountains"' (7:164n). ${ }^{25}$ At once indexing a present state of freedom with a reminder of prior states of unfreedom, the figure of the helm cloud condenses the "wilfulwávier" pulse of the skies, the complex interactions between volition and vagary, self-government and external restraint.

In other locations across Ruskin's cloud œuvre, the language of liberty occurs in various guises. The Elements of Drawing (1857) —still within the conceptual ambit of Modern Painters in stressing truth and precise observation in plein air sketching - invokes the practical figure of "leading or governing lines" (15:91). These had been introduced in the fourth volume of Modern Painters in a section on Alpine drawing. ${ }^{26}$ Although clouds are difficult to render with line, as noted above, in sketching them such lines become paramount in capturing the "sort of change which the ... vapour is at any moment enduring in its form" (15:91). It is this "change in shape," Ruskin goes on to argue, that "suggests the idea of their being individually free, and able to escape, if they liked, from the law that rules them, and yet submitting to it" (15:171). Leading lines thus represent, or at least give the impression of, contours governing liberty of shape and movement. The notion tacitly mobilizes William Blake's defense of the "bounding line" as an index of artistic perfection. ${ }^{27}$ It also complicates Ruskin's broader endorsement of color, in Elements of Drawing and elsewhere, in its longstanding rivalry with line and form in the history of art. ${ }^{28}$ Ruskin again invokes Turner to claim that the most compelling depictions of leading lines emphasize continuity and succession, capturing kinetic process rather than (false) monotony and regularity. ${ }^{29}$

Ruskin later allows his concern with representational accuracy and empirical knowledge to give way to myth and allegory. He describes the move in The Queen of the Air (1869) as a shift from observable phenomena to the "parallel imagery of moral principle" (19:300). At once naturalizing mythical narratives and refracting his argument for truthful representations through a historical optic, Ruskin defends the vital, felt, "instinctive truth in ancient symbolism" (19:292). He suggests that John Tyndall's explanation of the sky's blue confirms that Athena's "bright blue eyes . . . and the deep blue of her ægis" are "accurate mythic expressions of natural phenomena" (19:292). ${ }^{30}$ Similarly, Athena's physical sway over winds and clouds - and over their respective deities, all "subordinate to the ruling power of the air" (19:319) — becomes a mythical ratification of our knowledge of how the winds direct the clouds. The title of the first lecture, "Athena Chalinitis," highlights her role as the restrainer or bridler of Pegasus, 
the winged horse of Pindar that Ruskin calls a "flying cloud" (19:295n). Both seamstress and shepherdess, Athena condenses other figures of virtuous restraint, as the air that

\begin{abstract}
divides [the clouds], numbers, cherishes, bears them on its bosom, calls them to their journeys, waits by their rest; . . . spins and weaves their fleece into wild tapestry, rends it, and renews; and flits and flames, and whispers, among the golden threads, thrilling them with a plectrum of strange fire that traverses them to and fro, and is enclosed in them like life. ${ }^{31}(19: 386)$
\end{abstract}

Finally, when Ruskin assesses two orders of creature associated with Athena-birds and serpents-we see clouds associated with an animated figure of self-government: the "wild form of the cloud closed into the perfect form of the bird's wings" (19:386). He suggests that a bird is "little more than a drift of the air brought into form by plumes" (19:386), glossing this thought in images that recall Shelley's skylark, the form that "dost float and run; / Like an unbodied joy," "a cloud of fire." ${ }^{32}$ Ruskin swerves this depiction into a dutiful figure of rule and self-rule: "the air is in all its quills, it breaths through its whole frame and flesh, and glows with air in its flying, like a blown flame: it rests upon the air, subdues it, surpasses it, outraces it; - is the air, conscious of itself, conquering itself, ruling itself" (19:360). ${ }^{33}$

The later ubiquity of such moral appeal, especially in Ruskin's lectures at Oxford, validates in retrospect the more tacit figures of Modern Painters. In the inaugural Lectures on Art (Hilary Term, 1870), Ruskin joins realism in understanding and representation to an awareness of wider import, predicating knowledge of the exact causes of a thunder-cloud's structure on recognizing its underlying spiritual power. ${ }^{34}$ In The Eagle's Nest (Lent Term, 1872), lectures more explicitly bridging art and natural science, he suggests that the representation of such kindred phenomena as clouds and foam cannot be improved by scientific comprehension. ${ }^{35}$ And in his Lectures on Landscape (Lent Term, 1871), he likewise insists that clouds are, principally, the "means of nourishment and chastisement to men" (22:15).

Such statements are coeval with Ruskin's first observations of a meteorological phenomenon he took to be novel, the storm-cloud, a "dry black veil" judged to result from both industrial and moral pollution (27:132). A cloud befitting its ambient culture- "without any substance, or wreathing, or colour of its own" (27:132) —it is surely constituted of "poisonous smoke" but also fabricated of "dead men's souls" (27:133). In The Storm-Cloud of the Nineteenth Century (1884), the London 
Institution lectures in which Ruskin attempts prophetically to account for these conditions he had noticed from the 1870s, his moral appeal acquires an urgent undertow, contemptuous of science and insistent on Britain's gloomy spiritual prognosis. ${ }^{36}$ These malignant clouds are grotesque perversions of agency, personifications that darken other elements of the sky, admix their "own bitterness and malice" to winds from all directions (34:34), and blot out the sun and its "moral influence." ${ }^{37}$ The black cloud ushered along by a filthy plague wind is the exact inverse of all the clouds and skies that first stole Ruskin's attention, through which he defined meteorology in his youth as a discipline of the beautiful, a "science of the pure air, and of the bright heaven," and in which he found crucial vehicles for moral and political, as well as aesthetic exhortation (1:208).

\section{CLOUDING LIBERTY}

Ruskin's language places liberty in the skies, but it may be fairly objected that a picture of liberty hemmed in by so constant an appeal to restraint is hardly worth the name. Why would rapt attention to the skies entail not an exuberant paean to freedom but stern injunctions to obedience? This paradox can be resolved by shifting direction to the cloudiness, so to say, in Ruskin's view of liberty. I here return to the core of Modern Painters to solidify the link between liberty and clouds, through Ruskin's observations on the social and epistemological haze of modernity. I track his assessment of the distinct vision of liberty accompanying this cultural moment-liberty as negative, as radical noninterference - and attempt to generalize his critique and his more specific claims about the freedom of the artist across a number of other works. Although his terminological variety-obedience, modesty, government-suggests otherwise, Ruskin is consistent in renovating the concept of liberty so that it adopts forms of restraint, highest among them an inherent self-command. Ruskin's view of liberty can be profitably compared to a position in contemporary political theory, and his own distinctive view finds more vibrant conviction when he passes from social and artistic liberties to freedom in nature. Clouds thus return as the exemplars by which modern artists, and the society they instruct, lead us less to a unitary concept than to a fluid model of liberty, one that modulates the harmony between license and limitation.

In the third volume of Modern Painters, Ruskin examines semiotic assumptions governing representation in the history of art and literature. In medieval landscape clouds are often signs to be read, but in 
some cases, notably Dante Alighieri's Inferno, they are adduced only to be associated with evil and moral obscurity. Ruskin turns to modern landscape and its contrasting attention to "cloudiness":

\begin{abstract}
whereas all the pleasure of the mediæval was in stability, definiteness, and luminousness, we are expected to rejoice in darkness, and triumph in mutability; to lay the foundation of happiness in things which momentarily change or fade; and to expect the utmost satisfaction and instruction from what it is impossible to arrest, and difficult to comprehend. (5:317)
\end{abstract}

This cultural shift to an aesthetics of uncertainty requires an attempted realism in its depictions. Ruskin lauds the accurate portrayal of skies and introduces the notion of "aerial perspective" (5:317). He makes transient features of landscape a sine qua non of pictorial realism, defending aesthetic representations of clouds, rain, and mist, specifically in "our own England," and arguing further how little it is recognized "that the chief masters of the human imagination owed, and confessed that they owed, the force of their noblest thoughts, not to the flowers of the valley, nor the majesty of the hill, but to the flying cloud" $(7: 186){ }^{38}$ Clouds, rather than clear skies or manifest horizons, are held up as the spurs to virtuous thinking and truthful representations of the world. ${ }^{39}$

Yet this ascendant precision entails the return of attitudes that earlier cultural and aesthetic modes hoped to proscribe: "easily encouraged doubt, easily excited curiosity, habitual agitation, and delight in the changing and the marvellous, as opposed to the old quiet serenity of social custom and religious faith" (5:318). In this inchoately secularized aesthetics, knowledge and representation find only impermanent anchors in what Wordsworth calls the "unenduring clouds." ${ }^{40}$ For Ruskin, clouds may undermine established moral codes if we cannot adapt to the partial knowledge of which they are emblematic. "If we insist upon perfect intelligibility and complete declaration in every moral subject," he notes, "we shall instantly fall into misery of unbelief" (6:89). "Our whole happiness and power of energetic action," he continues, "depend upon our being able to breathe and live in the cloud" (6:89). Ruskin develops this view at length in the fourth volume of Modern Painters, defending the value of limited sight and knowledge, of having a sense of the inexhaustibleness of the visual field; positing that "unsearchableness" (6:103) can coexist with clear scenes and skies; and praising the "noble dimness" (6:91) that comes with realizing one's limitations and attempting a more minute perception. This laudatory account emerges from his description of the "mystery" in 
Turner, the "great representative of this nineteenth-century cloudiness" (6:73) who, breaking through "fetter and formalism" (5:390), reclaims obscurity and unintelligibility as signs of artistic excellence and moves "past clearness" to become "dark with an excess of light" (6:96). Ruskin concludes that "so far as the clouds are regarded, not as concealing the truth of other things, but as themselves true and separate creations, they are not usually beheld by us with enough honour; we have too great veneration for cloudlessness" (6:104).

As we have seen, one might infer a range of options for human action lived in the cloud: from expressions of individual agency against external interference, to self-government and the internalization of law. Modern cloudiness, on Ruskin's view, tends towards the former picture of liberty. In failing to live with partial knowledge we either demote the clouds and venerate clarity, or misconstrue the lessons of the skies and opt for unrestrained license. In this sense, Ruskin criticizes a newfound "love of liberty" in art, a resistance to formalism that typifies the wider cultural mode (5:319) ${ }^{41}$ Modern painters

delight in getting to the open fields and moors, abhor all hedges and moats; never paint anything but free-growing trees, and rivers gliding 'at their own sweet will'; . . . and, carrying the love of liberty even to license, and the love of wilderness even to ruin, take pleasure at last in every aspect of age and desolation which emancipates the objects of nature from the government of men. (5:319-20)

In their resistance to manicured hedges and walled moats, modern artists prize a liberty in its negative guise as freedom from-restraint or interference-whereas Ruskin feels that this is tantamount to refusing liberty as such, since any obedience to law or government might be deemed a hindrance. This, I take it, explains his allusion to Wordsworth's sonnet, "Composed upon Westminster Bridge, Sept. 3, 1803": waters moving by their "own sweet will" are, under a different description, waters bounded by their banks, just as clouds that express their own agency are, in an altered figure, clouds governed by the wind or temperature gradients, shepherded by Hermes or Athena. ${ }^{42}$ Ruskin returns to rivers and clouds, as I will show, to envision individual liberty within a structure of overall impediment. But I first want to press what it means to say that such waters, in liquid or vapor form, are free in spite of their restraints. Is the predicate free inherent in the natural object, or is it an imposition of the artist, a manifestation of the cultural tendency? If the cloudiness of modernity-its envelopment in a haze of partial knowledge and moral unmooring-has occasioned a revolt 
against the restraints of custom and duty, can a rapprochement between liberty and restraint be imagined, in Ruskin's terms?

Ruskin is vehement in his dislike for modern liberty and chary about its possible return to the domain of law. He begins to articulate this view during the hiatus in Modern Painters. Seven Lamps of Architecture, a theoretical prequel to Stones of Venice, contains a sustained disquisition on "how false is the conception, how frantic the pursuit, of that treacherous phantom which men call Liberty: most treacherous, indeed, of all phantoms; for the feeblest ray of reason might surely show us, that not only its attainment, but its being, was impossible" (8:248-49). Often he disregards the term "liberty," as though it might never escape its proximity to "license" (8:249). ${ }^{43}$ This doctrine acquires a fuller articulation in Queen of the Air, where Ruskin attacks the modern praise of liberty-and, implicitly, Mill's recent On Liberty - in paternalist tones. ${ }^{44}$ Presenting the case of a child "freely" choosing from a table of victuals, some of which may be poisoned, Ruskin remarks that generally "there is no choice . . . but it is similarly between life and death," for every "option of act" is framed in a similarly stark manner (19:125). ${ }^{45}$ Freedom here inverts the discriminating perception I described above, diminishing one's inferential capacity and making choices "more doubtful . . . by the increased dimness of [one's] sight” (19:125).

In this gloomy view, liberty is opposed to true "individuality" or "character," and can only end in universal dissolution-the "consummate freedom" of death, which gives "permission for every particle in the rotting body to leave its neighbour particle, and shift for itself" (19:126). As a companion to this degradation of the flesh, "all liberty is an equal corruption in mind" (19:126), a view memorably summarized in Fors Clavigera: "Liberty, whether in the body, soul, or political estate of men, is only another word for Death, and the final issue of Death, putrefaction: the body, spirit, and political estate being alike healthy only by their bonds and laws; and by Liberty being instantly disengaged into mephitic vapour" (28:402-3). ${ }^{46}$ These images of disaggregated particles and unbounded vapors suggest perversions of clouds, and Ruskin's creaturely types of liberty are similarly contorted, ignoble and affiliated with decay-fish, butterflies, snakes ${ }^{47}$ and flies, with their "angry republican buzz" (19:124). He summarizes the modern view in a set of snide aphorisms: "Lambs and fawns should be left free in the fields; much more bears and wolves"; "Misguiding is mischievous: therefore guiding is"; "A fence across the road is inconvenient; much more one at the side of it" (19:128-29). ${ }^{48}$ 
When Ruskin turns to art, his tone changes. He variously praises freedom of artistic expression and practice, particularly when writing about architectural craft. In Seven Lamps, in "The Lamp of Truth" section, he values the results of such liberty against all forms of cast or mechanized work for expressing individuality, humanity, and the "life and accent of the hand" (8:214). This claim is finely articulated in "The Nature of Gothic" section of Stones of Venice, where Ruskin argues that Gothic, in keeping with the Christian recognition of the worth and imperfection of the individual soul, necessarily opposes thoughtful, imperfect, human work to mindless, precise, mechanical work. He develops this into a critique of industrialism that occupies him from Unto this Last (1860) onwards. Freedom of hand expresses a liberty of soul that followers and commentators have expanded into a political program. ${ }^{49}$ Yet elsewhere a familiar paradox is visible. Relaying Giotto's boast about being able to "draw a circle unerringly," Ruskin suggests that this feat is only possible with a hand "under a control as absolute and accurate as if it were fastened to an inflexible bar of steel" (19:120). In his practical mode, he exhorts young painters to subdue freedom and feeling and attain a surgeon's "mechanical steadiness" (7:248), and recommends looking to the master whose hand, even in a hurry, is "under perfect government" (15:33n). Turner's "dash of the brush" in sketching the fleeting clouds, he notes, "is as completely under the rule of thought and feeling as its slowest line" (3:409).

This kind of argument leads Ruskin to claim that "All freedom is error," and that art can only become right if it is "intensely continent, restrained, and considered" (19:121). Thus the mild chiding of the 1850s returns as a stern indictment of modern deficiencies, ranging from hesitant timidity to vulgar impetuosity, a "looseness, flimsiness, or audacity" that is the "expression of an inner spirit of licence in mind and heart, connected . . . with the peculiar folly of this age, its hope of, and trust in, "liberty"' (19:122-23). Ruskin is still insisting on this subject in his inaugural lectures of the early 1870s, which conclude by deriding the moderns who brought "mystery, despondency, domesticity, sensuality" and the quality "of which nothing but evil ever comes, or can come-Liberty" (20:173), and counseling students to "Obey, and you also shall be free in time" (20:174). In contrast to his earlier distinction from classical models in Modern Painters, Turner is now seen (the foil here is the discipined Luini, purported student of Leonardo) as "a great painter amidst the elements of modern English liberty" (19:131). He is "helpless and guideless" and only "magnificent idiosyncrasy" saves his work from being warped by his licentious environment (19:132). 
Why the anomaly?50 How does Ruskin nominate "freedom" the most dreaded two-syllable word in English, while also defending the free expression of the Gothic craftsman (21:267)? Why does he suggest that in architecture, as in any other human work, nobility requires imperfection (where perfection can only result from slavery), where in a related discussion of elementary architectural forms, in The Laws of Fésole (1877-78), he declares that, ceteris paribus, the "more laws any thing, or any creature, interprets, and obeys, the more beautiful it is" (15:388)? The fulcrum that joins the freedom of "The Nature of Gothic" to the limitations on a free hand is, I claim, some sense of the justice of the control exerted. ${ }^{51}$ In arguing for the individuality and creative self-determination of the Gothic craftsman, Ruskin invokes a Christian framework within which freedom from the arbitrary dictates of a master is justified given broader obedience to the just prerogatives of God. Conversely, it is idle to justify the free hand of an apprentice in drawing or painting, since the consensual control of a master or school is no arbitrary abridgment of autonomy. One can resist being a slave in order to be a free person under divine government, but one consents to a form of bondage under artistic sway. Hence the explicit comment that the "nature of right freedom" entails obedience, work, and service, and seen in this way can constitute "liberty from care" (10:194). It is within this framework that Ruskin once praised the views of his friend Charles Eliot Norton, who wrote of liberty "in its nobler signification" as "possession of the power to do the Will of God."52

Several qualities, then, define Ruskin's liberty. It is opposed to error and feebleness, especially of a moral nature; it is compatible with just restraint in the form of help, guidance, paternalism, law, and even interference, whether physical or social; as a quality more to be deserved than held ${ }^{53}$ it is a matter of character and individuality when coupled to virtuous ends, so its ideal is an inherent, self-governing power; and in this it is force and life, not decay and death. Ruskin had insisted on something like this picture from early on. In the conclusion to a poem entitled "The Gipsies," submitted (unsuccessfully) for the Newdigate Prize at Oxford in 1837, we hear that freedom "unrestrained" is a "curse," and that "There's but one liberty of heart and soul, / A thing of beauty, an unfelt control" (2:40-41). This youthful view recalls Wordsworth's "Ode to Duty," with its serene accession to duty's sterner "controul" after a voluntary surrender of the "uncharter'd freedom" in which the speaker had been, like a recalcitrant cloud, "No sport of every random gust." ${ }^{54}$ 
Only later in the 1860s, perhaps in tacit response to Mill's work, does Ruskin begin to brand his view in classical and medieval terms. ${ }^{55}$ He glosses the Greek eleutheria, in Munera Pulveris (1872, originally in Fraser's Magazine, 1862-63), as "Liberality; a form of liberty quite curiously and intensely different from the thing usually understood by 'Liberty' . . . indeed, much more like what some people would call slavery," and suggests that the Greek understanding was "deliverance from the law of his own passions (or from what the Christian writers call bondage of corruption)" (17:227). In his lectures on Tuscan art, he invokes the Roman concept of libertas, suggesting that Gothic "liberty" is derived from the Latin for child, liber (23:109). Discussing differences between Greek and Gothic tempers-the former elsewhere glossed as "tranquil action," the latter as "passionate rest" (22:49-50)—Ruskin introduces a concept drawn from medieval French society: "franchise" or "frankness," the quality of free persons whose passions are under rule (23:116). Making franchise a cultural synonym for libertas and eleutheria, he opposes the notion to Mill's "liberty" and Hugo's "liberté" (23:116-17), and combines individual agency with self-command: "there is no limit to the freedom of the Gothic hand or heart, and the children are most in the delight and the glory of liberty when they most seek their Father's precepts" (23:117). ${ }^{56}$ An inculcated obedience is nobler than one imposed from outside. The "increase of both honour and beauty is habitually on the side of restraint (or the action of superior law)," Ruskin writes, although his idea of libertas sides with "character (or the action of inherent law)" (8:250) and noble, self-governing temperance-the Platonic sōphrosyne $(10: 395-96,22: 170-71) .^{57}$

In proffering this model, Ruskin opposes to modern liberty a quality that goes by several names. In Seven Lamps, he foreshadows his reflections in Modern Painters by making his seventh principle of architectural form that of "obedience" (8:248-66). Far beyond architecture "that principle . . to which Polity owes its stability" (8:248), obedience stands for a reasoned adherence to tradition and law, a "respect for all who are in authority" (8:249). A decade later obedience acquires a stark figure in "The Work of Iron, in Nature, Art, and Policy" (1858), a lecture published in The Two Paths (1859), where Ruskin discourses on fetters literal and figurative, praising the wise and noble "necessity of restraint" in a society (16:407). He criticizes the chatter about liberty, a thing "on the whole, and in the broadest sense, dishonourable, and an attribute of the lower creatures" (16:407), but exempts those creaturely types of noble, self-commanding restraint: 
bees, larks, swallows, ants. ${ }^{58}$ Ruskin sermonizes, "from the ministering of the archangel to the labour of the insect,-from the poising of the planets to the gravitation of a grain of dust, - the power and glory of all creatures, and all matter, consist in their obedience, not in their freedom. The Sun has no liberty - a dead leaf has much. The dust of which you are formed has no liberty. Its liberty will come-with its corruption" (16:408).

The paternalism of this view is clearer in a related, more plainly gendered term, "Modesty," the "unescapable law of wise restraint" (19:400), which Ruskin explains with an updated analysis of the free child: "No one ever gets wiser by doing wrong, nor stronger. You will get wiser and stronger only by doing right, whether forced or not; the prime, the one need is to do that, under whatever compulsion, till you can do it without compulsion" (19:125). ${ }^{59}$ Modesty, which Ruskin feels has been ignored or devalued in modern art, is a virtue that governs measure, mode, and limit, aiming at the "recognition of law, and delight in it, for the sake of law itself" (19:75). Alluding to an etymological link between "insolent” (“"custom-breaking,' violating some usual and appointed order to attain for itself greater forwardness and power") and "solemnity" (law as "accustomedness," in keeping with order), Ruskin moralizes his solemn account of moderated liberty against the wild insolence of the prevalent view (19:75) ${ }^{60}$ When in 1871 he promises to donate a tithe of his fortune to setting up a commonwealth within England, he stipulates in similar terms that, "We will have no liberty upon it; but instant obedience to known law, and appointed persons: no equality upon it; but recognition of every betterness that we can find, and reprobation of every worseness" (27:96) ${ }^{61}$

If Ruskin so sternly resists negative liberty, ridiculing its impractical emphasis on the absence of interference, and is ambivalent on the question of positive liberty, valuing release from the passions but questioning freedoms of thought, expression, and agency untrammeled by law, it seems worth asking whether we can clarify his account by turning to contemporary political theory. I want to put forward a recent, rival picture of negative liberty, the so-called republican theory, in an attempt at comparison. ${ }^{62}$

Taking inspiration from the Roman tradition and its inheritance in the English critics of the Stuart monarchy, the republican theory alters the terms of constraints on liberty. ${ }^{63}$ As Quentin Skinner argues, freedom on this model "is restricted not only by actual interference or the threat of it, but also by the mere knowledge that we are living in dependence on the goodwill of others," or "under an arbitrary power." 64 
Absence of domination or of dependence is thus more crucial than absence of interference: the "will can be autonomous" only if it is "also free from dependence on the will of anyone else," not merely when it is free of actual or threatened coercion; and, in a related claim, the effect of dependence is "to dispose us to make and avoid certain choices, ... to place clear constraints on our freedom of action," even if concrete or indicated interference never appears. ${ }^{65}$

Ruskin would blanch at being called a republican in any modern sense. Throughout his life he would remain wary of republican movements and their historical forebears in Europe-the French Revolution, the nationalist uprisings at midcentury, the Paris Commune of 1871 — and despaired at the architectural destruction he had seen wrought in Italy in $1848 .{ }^{66}$ Yet aspects of his thought retain elements of classical and early modern republicanism. His model of liberty is no exception. If we invert the terms of these rival accounts, we see that where negative liberty is opposed by interference or constraint as such, republican liberty is opposed by arbitrary power. There are clearly moments when Ruskin advocates the former position, preferring interference to license, but he never approaches the latter without qualifying the justice of any power on which we depend. He sees the individual as a free person in a wise and just polity, where actual or threatened restraint, when not arbitrarily imposed, need not limit freedom. Indeed, since we are all under the benign arbitrium of God and in the "perfect freedom" - a liturgical phrase — of divine service, consenting to an extreme of bondage is not tantamount to enslavement (29:138). ${ }^{67}$

Ruskin is careful to show that restraint is itself curtailed by the requirements of justice, for "when too great, ... [restraint] overpowers the nature of the thing restrained, and so counteracts the other laws of which that nature is itself composed" (8:250). It is a condition of human law that it is enforceable only "so far as it is just," so impediments are coherent within a model of freedom only insofar as they are not artifacts of an unjust discretionary power (23:115). This is a stipulation of the republican account that the negative theory has difficulty in parsing, since the latter perforce treats impediments as obstacles to freedom. In this light one might reframe Ruskin's more outrageous moments, as when he opposes the "slavery" of modern labor to the "life and liberty" (10:193) of Gothic expression — "a freedom of thought . . . such as no laws, no charters, no charities can secure" (10:194): 
Men may be beaten, chained, tormented, yoked like cattle, slaughtered like summer flies, and yet remain in one sense, and the best sense, free. ... [T] here might be more freedom in England, though her feudal lords' lightest words were worth men's lives ... than there is while the animation of her multitudes is sent like fuel to feed the factory smoke, and the strength of them is given daily to be wasted into the fineness of a web, or racked into the exactness of a line. (10:193)

As a statement uneasily tolerant of slavery, the sentiment is reprehensible, congruent with Ruskin's notorious support of Carlyle's committee to oppose the prosecution of Governor Edward John Eyre, after the latter's violent suppression of the Jamaican uprising in 1865. As a rhetorical shock tactic, a paradox by which Ruskin brings out the feel of a freedom not essentially threatened by restraint, his claim is theoretically striking. Indeed, it is similar to the contention that, on the republican view, even imprisonment need not curtail the essential liberty of an agent, under arrangements that are consensual and so take notice of the agent's will. ${ }^{68}$

Of course, there are many points on which Ruskin's views cannot be assimilated to the republican theory in its contemporary form. The latter implies some version of a consent theory, whereas Ruskin dismisses such democratic vanity and favors austere obedience. Still, even though it risks labeling his idiosyncratic account of liberty with a philosophical anachronism, refracting Ruskin's politics through this contemporary debate might usefully renovate the views of a figure often charged with incoherence-a reactionary Tory and "violent Illiberal" who may have done more to influence British socialism than Karl Marx, a Francophobe who derided the republican vogue but invoked classical republicanism to decry the tyranny of mechanized industrialism (27:14). Keeping the republican theory in mind allows us to see where Ruskin, despite himself, lets on that there may be some nobility in a version of liberty yoked to self-command. In a letter written to his father in 1845 from Florence, one of the originators of modern republicanism, he states: "I wanted to explain what I meant by saying . . . that I was getting more republican. I didn't, you see, mean more of a liberty man — of all the curses that poor, vicious, idiotic man can suffer, liberty is perhaps the greatest; but if one can be made to govern oneself, the exertion required to do so brings out a fine creature" $(8: 262 \mathrm{n} 2)$.

In Modern Painters, Ruskin had lauded the quality of "moderation" in beauty, its "government by law" (4:135), and declared "self-restrained liberty" (4:138) as the law of the universe. He recalls this moment in 
Stones of Venice, speaking of the Creation, an "image of that perfection of divine action, which, though free to work in arbitrary methods, works always in ... Laws," and suggesting that when we represent the natural entities of that Creation, we do best to make them an "image of the perfection of human action: a voluntary submission to divine law" (9:304). ${ }^{69}$ Yet, in turning from art and society to nature, such self-restrained libertas - not to mention republicanism-seems evasive. Internal government is rare, a figurative leap in the context of typically external restraints and visible boundaries: fences around a field, bridles on a horse, yokes on oxen. Returning to a familiar figure, Ruskin suggests that a river is free both when moving swiftly between banks and when meandering aimlessly in marshes. He notes that we too can choose "the restraint of voiceful rock, or the dumb and edgeless shore of darkened sand" (19:409). The unusual epithet "voiceful" seems to animate and dignify the process of restraint, just as an earlier citation of Wordsworth's "Resolution and Independence" shows how "repose" (4:115) in nature is proportionate in its beauty to the energy it has to curb, as in a cloud "That heareth not the loud winds when they call; / And moveth altogether, if it move at all." ${ }^{\text {70 }}$ Having earlier ventured an account of clouds as the interplay between liberty and restraint, I suggest, Ruskin inverts the figure in Seven Lamps and models liberty in terms of those natural figures that were previously the objects of inquiry:

Obedience is . . . founded on a kind of freedom, else it would become mere subjugation, but that freedom is only granted that obedience may be more perfect; and thus, while a measure of license is necessary to exhibit the individual energies of things, the fairness and pleasantness and perfection of them all consist in their Restraint. Compare a river that has burst its banks with one that is bound by them, and the clouds that are scattered over the face of the whole heaven with those that are marshalled into ranks and orders by its winds. (8:250)

Although they are not named, it is evident that Ruskin is describing cirrus formations, which across Modern Painters remain the exemplars of restrained freedom. The lack of discernible edges or restraining boundaries in the cirrus form allows its obedience to seem willed, dutiful rather than coerced. Ruskin judges them (as against "scattered" clouds) more apposite as models of restraint than the standard state of a "bound" river (as against one that "has burst its banks"). ${ }^{71}$ To recast the claim in Ruskin's other terms, clouds would seem naturally disobedient and insolent, immeasurable and immodest. There are 
no patently visible limits to their shape, size, movement, and even altitude. Similarly, liberty in Ruskin's terms is a blended concept-a model with fluid boundaries balancing will and agency against selfgoverning restraint-and so finds its most plausible and accessible figure in these bodies that manifest energy as well as voluntary subjection to natural laws.

In reframing natural forms in political terms, Ruskin comes up against competitor accounts of the liberty in nature and sets himself apart in striking fashion. In a note to Seven Lamps, he quotes the first stanza of Coleridge's "France: An Ode" (1798). The poem was written to protest French aggression against Switzerland (culminating in a decisive victory in early 1798), and thus to withdraw moral support from a France that had definitively shifted from revolutionary to imperial ideals. The poem's "Argument" describes its opening as an "invocation to those objects in Nature, the Contemplation of which had inspired the Poet with a devotional love of Liberty," in its French republican mode. ${ }^{72}$ In 1849, Ruskin tersely disparages Coleridge's "erring thought" (8:271); in 1880 he appends a scathing commentary, interpolated here:

Ye clouds, that far above me float and pause,

Whose pathless march no mortal may controul!

[If controlled by God, are they therefore more free?]

Ye ocean waves, that whereso'er ye roll,

Yield homage only to eternal laws!

[Is the ship they bear less noble in obeying those,

and her captain also? - and does she gain dignity in obeying her helm?]

Thou rising sun! thou blue rejoicing sky!

Yea, every thing, that is and will be free,

Bear witness for me, whereso'er ye be,

With what deep worship I have still ador'd

The spirit of divinest Liberty! ${ }^{73}$

[The rising sun has not been before noticed; nor does it appear why the author considers it more 'free' in rising than setting. Of all objects in Creation, the sun is the last which any rational person would think of as moving in 'the spirit of divinest Liberty,' or could wish that it should be permitted to do so.] $(8: 271)$

In criticizing Coleridge's glib, individualist use of liberty as an epithet for entities that obey natural laws, and are thus under a broader control, Ruskin reformulates his view that liberty in a social context should model itself on the natural objects with which it shares an obedience to law and duty ${ }^{74}$ These are the forces that, in Wordsworth's phrase, 
"preserve the Stars from wrong" and keep "the most ancient Heavens ... fresh and strong." " Yet unlike the sun and stars, clouds are scriptural ciphers for a shared medium between humanity and divinity, and they can come to form a stern yet flexuous image of law-abiding libertas for society and government on earth. In a work contemporary with these comments, The Bible of Amiens (1880-85), Ruskin will speak of "eternal laws enforced ... by the clouds and stars," as though intruding a distinctly cloudy feel into the starry skies of Wordsworthian duty and Kantian moral law (33:93).

\section{CONCLUSION}

In Seven Lamps, Ruskin turns unexpectedly from cornerstones to clouds and reminds us that our joy in contemplating them "results from the impression of their having luminous, warm, and mountainlike surfaces; and our delight in the sky frequently depends on our considering it as a blue vault," whereas we know that clouds are really "damp fog, or a drift of snow-flakes," and the sky "a lightless abyss" (8:62). Ruskin's relationship to these natural forms traces a similar partition between affective, aspectual responses and disenchanting, factual knowledge. Staking his truth in the former category, he recalibrates the intuitive freedom of clouds by means of an austere and tempered account of liberty, vying to reconcile this idea of libertas with the elaborate figures through which his political thinking occurs. He gradually submerges scientific explanations in a shifting condensate of myth, figure, and observation. Ruskin at once reliberates the clouds and clouds liberty, opting against meteorologies of freedom-precise in concept, stable in taxonomy, universal in applicability - in favor of figurative and aesthetic matrices, atmospheres of liberty that are variable, evolving, and local. The interpretive pliancy of clouds enables Ruskin to make them clear embodiments of his political views, and this seeming coherence is no mere trick of figure: he is not concerned "To make the shifting clouds be what you please," in Coleridge's phrase. ${ }^{76}$ Instead his figurative alternation captures the harmonizing of freedom and restraint, the fluid vision of liberty that matches the epistemic worldview of which clouds are emblematic, as well as the social arrangements they both model and encode.

Only clouds self-governing on high, however. Clouds are "gloriously arranged" because they "cannot be quarried nor built over" (15:129), and Ruskin felt that his culture had "packed [them] into iron cylinders" so that people might move at their "cloud pace," thus "forgetting the 
clouds" (5:383) and abjuring their moral instruction. He counsels that if life is "but a vapour that appears for a little time and then vanishes away, let it at least appear as a cloud in the height of Heaven, not as the thick darkness that broods over the blast of the Furnace, and rolling of the Wheel" (8:220). Seeing in such lines of commentary a trenchant prediction of the climate crises of late modernity, scholars have reclaimed Ruskin as an ecological theorist ahead of his time. ${ }^{77}$ In closing, I indicate how my account widens the purview of such claims by linking environmental arguments to theories of liberty, thereby merging the shifting strata of aesthetic, moral, and political concerns in a constantly flowing dissolve. Rather than espousing a straightforward concern for nature- on a simple analogy between natural forms and human concerns - the environmental stance we might infer from Ruskin's work turns on how the liberty of persons relates to large-scale systems and collectivities.

In the decades preceding Modern Painters clouds emerged as supple companion figures in artistic works. Ubiquitous in English Romantic poetry and painting, they hover suggestively in the background of representational artifacts that address, inter alia, social upheaval and vagrancy, war and revolutionary tumult. They thus emerge, in concert with developments in cloud science and classification, as paradigmatic figures for a "system no one individual could perceive," traversing geographical boundaries and requiring "an aerial, global, and theoretical stance." 78 Modern clouds, so to say, become figurative models for arrangements that yoke the minutely local to the regional and global, aery transnational bridges of which the filigree of jet trails across our skies are only a more literal index. Ruskin's cloud studies mimic this movement in aesthetic imagination-admiring English clouds while recalling Alpine forms, and vice versa-as well as in the account of liberty he reads in the skies. Drawing aspects of the different theoretical traditions of liberty together, I have brought out Ruskin's dialectical shuttling between the individual and the social, the local and the global, not to end with a stable hierarchy — as he has often been charged with sponsoring - but rather to acknowledge how his figures already build the singular into the systemic, both affecting one another at a distance.

Ruskin intuited how unbridled liberty had sponsored social and economic patterns that created - as they continue to create-changes in the very natural forms one might use to think through the constitutive freedoms of social life. His wide-ranging writings, and the decades of the nineteenth century during which he was by turns influential and 
infamous, remain productive sites for examining the crosscurrent of ecological concerns that are mutually predicated on social, political, and aesthetic considerations. Ruskin's work attunes us to a climatic theory of liberty, blurring the individual and the collective, particular modifications and broader atmospheres. In our uncertain, vaporous existence, the clouds we cannot make offer images of "majestic subjection," apt models of liberty for lives made of water (8:251). By attending to the persistently "wilful-wávier" dynamic in the clouds_-and their floating presence in aesthetic representations - we might envision flexible ways to generalize liberty's requirements across our collective "dewy existence" (4:139), extending the privileges of lives "in the cloud" (6:89) to those less at liberty and preserving an atmosphere in which the images of liberty can float free.

\section{Harvard University}

\section{NOTES}

${ }^{1}$ John Ruskin, Modern Painters I, in The Works of John Ruskin, 39 vol., ed. E. T. Cook and Alexander Wedderburn (London: George Allen, 1903-1912), 3:344. Hereafter cited parenthetically by volume and page number.

${ }^{2}$ Elizabeth K. Helsinger sees Ruskin's "evangelical teacher" role in evidence here (Ruskin and the Art of the Beholder [Cambridge: Harvard Univ. Press, 1982], 16-17).

${ }^{3}$ Gerard Manley Hopkins, "Hurrahing in Harvest," in The Poetical Works of Gerard Manley Hopkins, ed. Norman H. MacKenzie (Oxford: Clarendon Press, 1989), 148. I include Hopkins's metrical marks, but omit the outride mark under the word "walks."

${ }^{4}$ Peter Quennell asserts that the "austere" Ruskin "forgot to be a moralist" in respect of clouds (John Ruskin: The Portrait of a Prophet [New York: Viking Press, 1949], 29).

${ }^{5}$ Raymond Williams, Culture and Society, 1780-1950 (New York: Harper \& Row, 1966), 141. Linda C. Dowling argues that Ruskin wrote Stones of Venice during a brief "window of aesthetic liberalism," in harmony with a tradition of "Whig aesthetics," only to recede into authoritarianism in later years after losing his faith (The Vulgarization of Art: The Victorians and Aesthetic Democracy [Charlottesville: Univ. of Virginia Press, 1996], 25-49, 27). David Wayne Thomas discovers a tacit rhetoric of liberalism and individualism in Ruskin, suggesting that he espouses through metaphoric procedures "a liberal many-sidedness loathe to speak its name" (Cultivating Victorians: Liberal Culture and the Aesthetic [Philadelphia: Univ. of Pennsylvania Press, 2004], 49-81, 56-57). See Judith Stoddart, Ruskin's Culture Wars: Fors Clavigera and the Crisis of Victorian Liberalism (Charlottesville: Univ. of Virginia Press, 1998), 5-11, 46-65, for Ruskin's political writing in relation to the period's liberal politics; and Caroline Levine, The Serious Pleasures of Suspense: Victorian Realism and Narrative Doubt (Charlottesville: Univ. of Virginia Press, 2003), 21-36 for a convincing reading of aesthetics and radicalism. Rachel Teukolsky also provides a sketch of what she terms Ruskin's "political botany" in The Literate Eye: Victorian Art Writing and Modernist Aesthetics (Oxford: Oxford Univ. Press, 2009), 164.

${ }^{6}$ On Ruskin's aesthetics, for instance, see Robert Hewison, John Ruskin: The Argument of the Eye (Princeton: Princeton Univ. Press, 1976), 119-47, esp. 130-32 recognizing 
the analogy between nature and social order. In later work, Hewison reads Ruskin against the backdrop of Tory radicals like Robert Southey, William Wordsworth, and Samuel Taylor Coleridge. See "Notes on the Construction of Stones of Venice," in Studies in Ruskin: Essays in Honor of Van Akin Burd, ed. Robert Rhodes and Del Ivan Janik (Athens: Ohio Univ. Press, 1982), 131-52. Other crucial studies in this line include John D. Rosenberg, The Darkening Glass: A Portrait of Ruskin's Genius (New York: Columbia Univ. Press, 1961) and George P. Landow, The Aesthetic and Critical Theories of John Ruskin (Princeton: Princeton Univ. Press, 1971). On Ruskin's political and social views, see P. D. Anthony, John Ruskin's Labour: A Study of Ruskin's Social Theory (Cambridge: Cambridge Univ. Press, 1983), 9-28; Jeffrey L. Spear, Dreams of an English Eden: Ruskin and His Tradition in Social Criticism (New York: Columbia Univ. Press, 1984); and Gill G. Cockram, Ruskin and Social Reform: Ethics and Economics in the Victorian Age (London: Tauris, 2007), 1-39. See also David M. Craig, John Ruskin and the Ethics of Consumption (Charlottesville: Univ. of Virginia Press, 2006) for an account of economics and religious ethics; Günther Leypoldt, "Aesthetic Specialists and Public Intellectuals: Ruskin, Emerson, and Contemporary Professionalism," Modern Language Quarterly 68 (2007): 417-36 for Ruskin's position in the Victorian intellectual field; and Stuart Eagles, After Ruskin: The Social and Political Legacies of a Victorian Prophet, 1870-1920 (Oxford: Oxford Univ. Press, 2011), 1-26 for Ruskin's legacy and its effect on critiques of his politics.

${ }^{7}$ Marjorie Levinson, "Of Being Numerous," Studies in Romanticism 49 (2010): 634. See Mary A. Favret, War at a Distance: Romanticism and the Making of Modern Wartime (Princeton: Princeton Univ. Press, 2010), 119-44 for the argument that a newly global meteorology and weather metaphorics in the Romantic period "provided forms for mediating distant war" (120). See Mary Jacobus, Romantic Things: A Tree, A Rock, A Cloud (Chicago: Univ. of Chicago Press, 2012), 10-35 for a reading of the clouds of John Constable and John Clare as tracking moods and mental states. Marjorie Levinson deploys various materials (Luke Howard's cloud theory, Baruch Spinoza's account of extended substance, Georg Cantor's theory of transfinite numbers) to read Wordsworth's poem "I wandered lonely as a Cloud" as an "experiment in social ontology" (643), a way to imagine an ensemble individuality that is "already multiple, diverse, and dynamically continuous with its environment" (635).

${ }^{8}$ In Lectures on Landscape (1871), Ruskin adverts to "the type of human life, born of the cloud and vanishing into the cloud" (22:69). By The Art of England (1883) the thought has darkened: "What is glorious and good in the heavenly cloud, you can, if you will, bring also into your lives, - which are indeed like it, in their vanishing, but how much more in their not vanishing, till the morning take them to itself' (33:392-93).

${ }^{9}$ Wordsworth's influence on Ruskin has been amply documented by Helsinger. See Helsinger 41-110 for her assessment of his developing historical critique of Wordsworthian modes of perception, and his reliance on The Excursion for a model of art and landscape literature inflected by travel writing and an active, democratic, "excursive sight" (69). Other appraisals include Jonathan Bate, "Wordsworth, Ruskin, and the Moral of Landscape," Literature and Belief 10 (1990): 1-23; John Beer, "Ruskin and Wordsworth," The Wordsworth Circle 28 (1997): 41-48, expanded in Providence and Love: Studies in Wordsworth, Channing, Myers, George Eliot, and Ruskin (Oxford: Clarendon Press, 1998), 233-312; and Dinah Birch, "Elegiac Voices: Wordsworth, Turner, and Ruskin," The Review of English Studies 50 (1999): 332-44. Ruskin often praises Wordsworth's truthful skies in Modern Painters (see 3:347, 353, 363). 
${ }^{10}$ Ruskin's interest in meteorology is present from one of his earliest publications, "Remarks on the Present State of Meteorological Science" (1:206-10, originally in Transactions of the Meteorological Society 1 [1839]: 56-59). He typically relied on outdated sources, yet his insistence on precise observation and detailed phenomenological response has attracted the interest of geographers and meteorologists. See Katharine Anderson, "Looking at the Sky: The Visual Context of Victorian Meteorology," The British Journal for the History of Science 36 (2003): 314-17; Denis Cosgrove and John Thornes, "Of Truth of Clouds: John Ruskin and the Moral Experience of Order in Landscape," in Humanistic Geography and Literature: Essays on the Experience of Place, ed. Douglas C. D. Pocock (London: Croom Helm, 1981), 20-46; and Cosgrove, "John Ruskin and the Geographical Imagination," Geographical Review 69 (1979): 43-62.

${ }^{11}$ Ruskin uses Howard's Latinate terms, cirrus, cumulus, and stratus, and the compound cirrostratus (see 3:384). He never uses nimbus or cumulo-cirro-stratus (the rain-cloud), and initially warps the arrangement by referring to cloud types dictated by altitude, where Howard's system sought to describe clouds as modifications, forms in movement. There is no evidence, however, that Ruskin knew of Howard's On the Modifications of Clouds (London: J. Taylor, 1803). For the history of cloud classification and its place in landscape art, see Richard Hamblyn, The Invention of Clouds: How an Amateur Meteorologist Forged the Language of the Skies (New York: Farrar, Straus and Giroux, 2001); Kurt Badt, John Constable's Clouds, trans. Stanley Godman (London: Routledge \& Kegan Paul, 1950); Thornes, "Luke Howard's Influence on Art and Literature in the Early Nineteenth Century," Weather 39 (1984): 252-55, "A Brief History of Weather in European Landscape Art," Weather 55 (2000): 363-75; and John Constable's Skies: A Fusion of Art and Science (Birmingham: Univ. of Birmingham Press, 1999), 191-96.

${ }^{12}$ Wordsworth, "I wandered lonely as a Cloud," in Poems, in Two Volumes, and Other Poems, 1800-1807, ed. Jared Curtis (Ithaca: Cornell Univ. Press, 1983), 207-8. See Levinson, 640-41 on the reading of "host" as military trope.

${ }^{13}$ Slightly misquoted on 3:364. The lines are spoken by Asia, one of the Oceanids, and read: "We wandered, underneath the young grey dawn, / And multitudes of dense white fleecy clouds / Were wandering in thick flocks along the mountains, / Shepherded by the slow, unwilling wind" (Percy Bysshe Shelley, Prometheus Unbound, in Shelley's Poetry and Prose, ed. Donald Reiman and Neil Fraistat, 2nd ed. [New York and London: Norton, 2002], 239).

${ }^{14}$ Elements of Drawing (1857) offers a more eloquent statement: clouds are "definite and very beautiful forms of sculptured mist ... the warm air around them cutting them into shape by absorbing the visible vapour beyond certain limits" (15:130).

${ }^{15}$ See Helsinger, 67, 148-50 for Ruskin's early reading of Horace-Bénédict de Saussure.

${ }^{16} \mathrm{~J} . \mathrm{M}$. W. Turner's original watercolor and gouache drawing, from which engravings and photogravures were made, is now in The J. Paul Getty Museum, Los Angeles; see European Drawings 2: Catalogue of the Collections, ed. George R. Goldner and Lee Hendrix, with Kelly Pask (Malibu: J. Paul Getty Museum, 1992), 321-22. I generally furnish images to give a sense of how Ruskin's arguments are supplemented referentially, even though his volumes only carried occasional illustrations from Seven Lamps on and he was typically skeptical of engraving and other forms of surrogate reproduction.

${ }^{17}$ Cosgrove and Thornes point to Ruskin's updated focus on "cloud physics" (30-34). Ruskin's turn to historical topics through Stones of Venice is fully demonstrated by Helsinger, 35-36, 43-44, 140-43, and updated by C. Levine. 
${ }^{18}$ For a reading of Ruskin's clouds in the final volume, in connection with his wider interest in water, see Carmen Casaliggi, "The Wide Significance of the 'Art of Clouds' in Ruskin's Modern Painters V," Rivista di Letterature Moderne e Comparate 62 (2009): 37-52.

${ }^{19}$ See Helsinger, 201-31 on Ruskin's symbolic language and figural interpretation and compare Raymond E. Fitch, The Poison Sky: Myth and Apocalypse in Ruskin (Athens: Ohio Univ. Press, 1982), 281-83 for a more mythopoetic account.

${ }^{20}$ Saussure approves of the vesicular account in his Essais sur l'hygrométrie (Neuchatel: Fauche, 1783), 282-311, validating his claims through dubious observational experiments with soap bubbles and vapor. The theory may have held more sway on the Continent than in Britain: Ludwig F. Kaemtz entertains it in A Complete Course of Meteorology, trans. C. V. Walker (London: Hippolyte Baillière, 1845), 109-24; but it is challenged by, among others, Howard (see Hamblyn, 32-34); his acolyte Thomas Forster, Researches about Atmospheric Phænomena, 3rd ed. (London: Harding, Mavor, and Lepard, 1823), 95-98; and Augustus Waller, "Microscopic Observations on the So-Called Vesicular Vapours of Water, as Existing in the Vapours of Steam, and in Clouds, \&c," Philosophical Transactions of the Royal Society of London 137 (1847): 23-30. On the sky's blue, see Peter Pesic, Sky in a Bottle (Cambridge: MIT Press, 2005), 95-118; and Cosgrove and Thornes, 26. John William Strutt (later Lord Rayleigh) explained the scattering of light by atmospheric particles in "On the Light from the Sky, its Polarisation and Colour," Philosophical Magazine (Series 4) 41 (1871): 107-20, 274-79.

${ }^{21}$ Ruskin's exchange with Oliver Lodge highlights how incompletely he was aware of scientific developments. To the claim that clouds are minuscule drops of water falling through the air, lifted by currents but never floating, Ruskin grumbles that this misses the "primary question ... - what gives a cloud its boundary?" (37:514), an issue he raises explicitly in Modern Painters (see 7:140) and reiterates in Storm-Cloud (see 34:46-8). He disputes a theory that cirrus formations are caused by airwaves, reacts with astonishment to a description of Brownian motion, and with interest to the fact that clouds form around condensation nuclei like dust (see $37: 517,520-1,524$ ). For a more generous view of this correspondence, see Francis O'Gorman, "Ruskin and the Scientists: John Lubbock and Oliver Lodge," The Ruskin Gazette 1.9 (1996): 9-18.

${ }^{22}$ The Postscript was drafted for Coeli Enarrant in 1884, although publication of this excerpt from Modern Painters - "The Firmament"; "The Cloud-Balancings"—was delayed until 1885. Ruskin's belief in the vesicular account persists in Storm-Cloud, where he rehearses the notion that clouds are floating vapor and notes that scientists have not settled the issue (34:14-17, 46-47). On Coeli Enarrant, see Stephen Wildman, "Coeli enarrant saepenumero: New Light on Dark Clouds," Ruskin Review and Bulletin 5.2 (2009): 79-81. For a mythological reading of Ruskin's clouds in Modern Painters $V$, see Fitch, 339-55.

${ }^{23}$ Jacobus, 11, 13. Her comments on Ruskin are limited to Modern Painters III (see Jacobus, 20-25).

${ }^{24}$ Despite his criticisms of scientific method, Ruskin often corrects himself. In Storm-Cloud he reiterates that this explanation of lee side clouds holds more water than John Tyndall's theory (see 34:49-51). Yet in Præterita (1885-89) Ruskin describes a helm cloud over Mont Blanc and notes that the formation "has always seemed most unaccountable to me" (35:455).

${ }^{25}$ In Queen of the Air (1869) Ruskin provides a more favorable link for this figure, relating the cap worn by Hermes to the epithet "cloud-capped," again mentioning 
Mount Pilatus (19:322). For etymological discussion, see Oxford English Dictionary, 2nd ed., s.v. "pileus, n."

${ }^{26}$ See 6:231-32.

${ }^{27}$ William Blake, A Descriptive Catalogue (1809), in Alexander Gilchrist, Life of William Blake, 2 vol. (London and Cambridge: Macmillan, 1863), 2:142-43. For a suggestive political reading of Blake's notion, see Peter Otto, "Politics, Aesthetics, and Blake's 'bounding line," Word \& Image 26 (2010): 172-85. As collected in Gilchrist, Blake's comments precede his "Public Address," a text Ruskin cites elsewhere (19:56). Earlier, in Seven Lamps, Ruskin places aesthetic value on the "bounding line" of an unbroken architectural contour (8:106). He may have come across the concept through his association with George Richmond and the early, private reception of Blake, having attempted to purchase several of Blake's works in 1843 and viewed many in the collection of Dante Gabriel Rossetti. See Tim Hilton, John Ruskin: The Early Years (New Haven: Yale Univ. Press, 1985), 60, 208-10. Ruskin often pairs Blake with Turner (see $8: 256 \mathrm{nl} ; 22: 470)$, stressing his strength of line and treating him as another uncultivated English genius, compromised by license, ending "in a conscientious agony of beautiful purpose and warped power" (19:133).

${ }^{28}$ See 15:133-61. In Modern Painters I, "truths of colour" (3:159) are secondary to those of line and form, both for art history and pedagogy (see 3:158-62), but the power of color is acknowledged in a defense of Turner as painting's supreme colorist (see 3:277-301). In later texts—including Addresses on Decorative Color (1854; reported in 12:477-508); a discursive note to Modern Painters V (7:414-19n); Lectures on Art (1870; 20:166-79); Lectures on Landscape (22:49-70); and Laws of Fésole (15:432-39)—Ruskin's justification adopts the dynamic framework of freedom (color) and restraint (line): the enriching aspects of color follow on correct linear form and are attendant only on its restrained pursuit. Helsinger, "Ruskin and the Aesthetics of Color," Nineteenth-Century Prose 35.1 (2008): 13-36 places Ruskin on the color side of a debate that ranges from the Renaissance (colore versus disegno) and seventeenth century (Poussinistes versus Rubénistes) to Ruskin's time (Romanticism, in the defenses of color, sense, and imagination in Keats, Shelley, and Hazlitt, against Neoclassicism, in the linear strictures of Reynolds). She sets Ruskin's opinion of historical color (in Florentine art), "securely contained within lines and shapes and put in service of a restrained devotion," against Turner's modern color (26). Compare Landow, 144-46, 429-30; Teukolsky, 38-39, 57-61 on Ruskin's expressivist color language as moving beyond his early critique; and Jonah Siegel, Desire and Excess: The Nineteenth-Century Culture of Art (Princeton: Princeton Univ. Press, 2000), 191-92 on Ruskin's dismissal of neoclassical "outline."

${ }^{29}$ See 15:170-72.

${ }^{30}$ Tyndall, "On Chemical Rays, and the Light of the Sky," Notices of the Proceedings of the Royal Institution of Great Britain 5 (1869): 429-50.

${ }^{31}$ These figures pick up earlier ones in Modern Painters that, as Jacobus suggests, issue from the texture of nineteenth-century industrial activities: spinning, embroidery, engraving. See Jacobus, 21-22. Although the goddess of air generally controls the "heavenly flocks" (19:386), Ruskin also nominates Hermes the "cloud shepherd" (19:322) and the "spirit of the movement of the sky" (19:324), and suggests that he is represented by Turner's sketch of the valley of Cluses (see 22:69-70). Elsewhere Hermes is associated with cumulus clouds (see 20:150, 152).

${ }^{32}$ Shelley, "To a Skylark," in Shelley's Poetry and Prose, 304; Ruskin also refers to Wordsworth's poem, "To a Sky-Lark" (see 34:308). That Shelley's poem was published 
along with Prometheus Unbound, in the company of poems such as the "Ode to the West Wind," "The Cloud," and "Ode to Liberty," reveals how a similar figurative nexus can be yoked to a more avowedly republican, not to say radical, politics. Shelley also had a substantial interest in meteorology: "The Cloud" illustrates Howard's taxonomy without naming his specific terms. See Hamblyn, 215-17; and F. H. Ludlam, "The Meteorology of the Ode to the West Wind," Weather 27 (1972): 503-14. For Ruskin's relationship to Shelley's poetry, from early inflections in the style of Modern Painters to later dismissals of the poet's sensitivity and self-reflexive view of nature, see Catherine Maxwell, "Sensitive Plants: Shelley's Influence on Ruskin," Durham University Journal 87 (1995): 31-41.

${ }^{33}$ The figures of bird and serpent are, it should be noted, mutually informing. For a reading of Queen of the Air attuned to these oscillations, see Sharon Aronofsky Weltman, "Mythic Language and Gender Subversion: The Case of Ruskin's Athena," Nineteenth-Century Literature 52 (1997): 350-71. Weltman argues for a "fluid concept of gender" in Ruskin (355).

${ }^{34}$ See $20: 53$.

${ }^{35}$ See 22:212-14

${ }^{36}$ Thornes and Gemma Metherell suggest that Ruskin here engages in what Vladimir Janković calls "meteoric reportage," the mode of weather observation prior to the nineteenth century that privileged singular, often unaccountable phenomena ("Monet's 'London Series' and the Cultural Climate of London at the Turn of the Twentieth Century," in Weather, Climate, Culture, ed. Sarah Strauss and Benjamin S. Orlove [Oxford: Berg, 2003], 144).

${ }^{37}$ Ruskin, The Diaries of John Ruskin, 3 vol., ed. Joan Evans and John Howard Whitehouse (Oxford: Clarendon Press, 1956-59), 3:1130. This is a diary entry from 1886.

${ }^{38}$ Ruskin's patriotic localism gives a negative spin to eighteenth-century British climatology, which had espoused a "political identity and extoll[ed] the virtues of the island climate for fostering liberty," for he resists precisely this climatic virtue in Modern Painters V (see 7:175-78) (Favret, 128).

${ }^{39}$ Ruskin's relationship to realism was productively complex. George Levine discusses the tension between his realism and the romantic, beautiful, and moral aspects of landscape (The Realistic Imagination: English Fiction from Frankenstein to Lady Chatterley [Chicago: Univ. of Chicago Press, 1981], 204-26). On the epistemological stakes of Ruskin's realism, see Jules David Law, The Rhetoric of Empiricism: Language and Perception from Locke to I. A. Richards (Ithaca: Cornell Univ. Press, 1993), 204-44 and Peter Garratt, "Ruskin's Modern Painters and the Visual Language of Reality," Journal of Victorian Culture 14 (2009): 53-71. On Ruskin's realism as a mediating aesthetic, see John P. McGowan, Representation and Revelation: Victorian Realism From Carlyle to Yeats (Columbia: Univ. of Missouri Press, 1986), 75-100, who interprets his clouds as materializations of spiritual tenets and figures for linguistic or semiotic mediation. C. Levine likewise emphasizes the effortful mediation of what she calls Ruskin's "laboring aesthetic" (25). Ruskin resists technologically mediated realism, dismissing photography for losing natural effects even as it captures form (see 6:81-82).

${ }^{40}$ Wordsworth, The Excursion, ed. Sally Bushell, James A. Butler, Michael C. Jaye (Ithaca: Cornell Univ. Press, 2007), 276. Murray Roston, Changing Perspectives in Literature and the Visual Arts, 1650-1820 (Princeton: Princeton Univ. Press, 1990), 342-53 links Ruskin to a secular trend in English Romantic painting-epitomized by Gainsborough, Constable, and Turner-where the divine heavens are foreclosed in favor of representing terrestrial landscapes and local weather. 
${ }^{41}$ I differ from critics who see this liberty as merely a formal freedom of craft: "delight in decoration, in variety, in embroidery, in ornamentation" (McGowan, 82-83).

${ }^{42}$ The complete line reads: "The river glideth at his own sweet will" (Wordsworth, Poems, 147).

${ }^{43}$ Originally, license meant not an abuse of liberty but an escape from default unfreedom, through leave or permission "to do something" (Oxford English Dictionary, 2nd ed., s.v. "licence, n.," def. 1 and 2).

${ }^{44}$ Much of this discussion Ruskin inserts from an earlier text, The Cestus of Aglaia (Art Journal, 1865 and 1866), which reflects on art in relation to virtue and national character.

${ }^{45}$ This is no thought experiment. In an 1870 lecture, "The Story of Arachne," Ruskin recounts how his mother once allowed him to touch a boiling tea-urn to yield a "first lesson in the meaning of the word Liberty" (20:372). Compare a contemporaneous comment in a letter to Charles Eliot Norton: "This Italy is such a lovely place to study liberty in! There are the vilest wretches of ape-faced children . . . throwing stones at the carvings ... that were ever left to find the broad way to Hades without so much as a blinker, let alone a bridle" (Ruskin to Norton, 21 June 1869, in The Correspondence of John Ruskin and Charles Eliot Norton, ed. John Lewis Bradley and Ian Ousby [Cambridge: Cambridge Univ. Press, 1987], 143). Ruskin's upbringing-his mother's stern Evangelical creed, his father's overbearing censorship—is often linked to his moral outlook. See Rosenberg, 110-11, 116-19; and James Clark Sherburne, John Ruskin or the Ambiguities of Abundance: A Study in Social and Economic Criticism (Cambridge: Harvard Univ. Press, 1972), 222-26. In Præterita, Ruskin realizes that the "ceaseless authority" of his parents precluded real independence, for "the bridle and blinkers were never taken off me." Softening his earlier comments, he recommends that a child needs some license, "set on the barebacked horse of its own will, and left to break it by its own strength" (35:46). He similarly realizes that what he enjoyed most about the mountains of the Jura, despite his "Tory prejudice," was the freedom to walk where one liked: an "effectual, not merely theoretic, liberty" (35:163).

${ }^{46}$ In Rock Honeycomb (1877), Ruskin labels nomos in the Psalms as the "guardian Law of Life," linking license to lawlessness (anomia) and death, obedience to life (31:122).

${ }^{47}$ See 16:407 and 20:292-93.

${ }^{48}$ Compare a diary entry in 1875 where Ruskin notes that an article of the Creed of St. George might be: "Believe in Almighty, i.e. in a Law, ascertainable as the will of a Governor. Compulsion according to that is a duty." He then sketches the opposed view: "John Mill Liberty—nobody to be guided" (Diaries, 3:866-67).

${ }^{49}$ In the contemporaneous pamphlet Pre-Raphaelitism (1851), Ruskin criticizes that school for not seeing that nature's freedom of line requires a corresponding free hand (see 12:388-89). Helsinger, 140-41, 158-61 surveys the assessments of "The Nature of Gothic" as initiating Ruskin's social criticism and stresses his new historical selfconsciousness. "The Nature of Gothic" has been seen as a "liberal tract" (Sherburne, 53) and a "manifesto for aesthetic democracy" (Dowling, Vulgarization of Art, 28), despite its vision of a merely local freedom built into hierarchy. See Sherburne, 41-54, which points to the section's intellectual backgrounds in Edmund Burke, Blake, Wordsworth, Coleridge, and Carlyle. Leypoldt examines its blend of Romantic social criticism with professional art criticism through a "rhetoric of cultural parallelism" (424), which combines technical formalism with sociomoral commentary to press the "symptomatic resemblance between aesthetic and social forms" (427). See also Anthony, 45-71; Thomas, 66-70; and Cockram, 18-20. 
${ }^{50}$ It is not that Ruskin praises freedom in architecture and shifts position thereafter. Writing to Norton in the 1880s, he still values the "Liberty" of line" in Gothic, noting that its English version has so forceful a "free hand in the curves" that it is impossible to copy "even the apparent circles with compasses" (Ruskin to Norton, 3 October 1882, in Correspondence, 450). Similarly, a diary entry in 1873 recalls his work on "Greek and Gothic" as "insisting much on freedom against Law" (Diaries, 2:762). Sherburne, 83, 219-20, gives a sketch of Ruskin's views on liberty but still insists that the liberty of Gothic contradicts the later positions. For further comments on Ruskin's opinions on liberty, see Anthony, 29-35, who notes its place in a framework of justice, authority, and obedience; and Eagles, 38-41, who discusses his attack on liberty and insistence on benign authority within the context of political economy. Cockram records Ruskin's influence on the economist J. A. Hobson in the development of a "new liberalism" (157). Sara Atwood, Ruskin's Educational Ideals (Farnham \& Burlington: Ashgate, 2011) sees his views as shaped by the early influence of classical study, especially Plato: "true liberty is obedience" (95).

${ }^{51}$ Anthony sees Ruskin's alternative society as "based on a passionate conviction of just and honourable relationships" (7). He notes that the Gothic craftsman belongs to a style of ornamentation Ruskin earlier classifies as "revolutionary," as opposed to "servile" and "constitutional," where subordinates have either no liberty or only a "measure of licensed or controlled freedom" (50).

${ }^{52}$ Ruskin to Norton, 28 February 1858, in Correspondence, 43. These two phrases are from Norton, Considerations on Some Social Theories (Boston: Little, Brown, 1853), 26; for his discussion of liberty, see 23-38. Norton's early work was framed by the events of 1848; he would later become a follower of John Stuart Mill's liberalism, which troubled his correspondence with Ruskin in the years leading up to Mill's death in 1873. See Dowling, Charles Eliot Norton: The Art of Reform in Nineteenth-Century America (Hanover: Univ. Press of New England, 2007), xiv-xvi, 3-5, 135-36.

${ }^{53}$ See 19:124.

${ }^{54}$ Wordsworth, Poems, 106. Ruskin would have been familiar with this poem through his general reading of Wordsworth; he alludes to it later in Fiction, Fair and Foul (1880), essays that typify his more critical stance towards Wordsworth's solipsism (34:323-24). In a diary entry in 1847, Ruskin offers some thoughts on the different springs of duty, including discipline, joy, and external obedience, and excluding any expectation of a (future) reward (Diaries, 1:353-54).

${ }^{55}$ Regarding political economy, Ruskin often attacked Mill, accusing him of being the "root of nearly all immediate evil . . . in England" (Ruskin to Norton, 12 September 1869, in Correspondence, 172). On the topic of liberty there is less engagement. Ruskin's annotations to his copy of On Liberty are approving, but he also pillories the notion of individual as against social rights (see 34:707-8). Although he praises Mill in Modern Painters (see 7:229), he discards his views at several points, arguing for law and restraint as political necessities in Time and Tide (1867) (see 17:371-2) and disapproving of Macaulay's remark that "the only cure for Liberty is more liberty" (27:106, 114; compare 29:96). Fors Clavigera (1871-84) is generally critical of "liberty-mongers" (29:340). Ruskin can find "much that is true in the part of Mr. Mill's essay on Liberty which treats freedom of thought," but he corrects what he sees as an incomplete picture with his own definition: "The degree of liberty you can rightly grant to a number of men is commonly in the inverse ratio of their desire for it" (19:127). Critics have argued that Ruskin and Mill are closer in their views than the former admitted. See Rosenberg, 31-32, 142-43; Sherburne, 52, 119-21; Cockram, 90-91, 114-15; and Donald Winch, 
Wealth and Life: Essays on the Intellectual History of Political Economy in Britain, 1848-1914 (Cambridge: Cambridge Univ. Press, 2009), 91-120.

${ }^{56}$ In Letter 43 of Fors Clavigera (1874), subtitled "French Freedom" and previously "Franchise" (28:106n1), Ruskin comments on how the French gave name to the concept of freedom, even though the Roman libertas is a truer notion, and criticizes the English version (see 28:113-15). Compare The Bible of Amiens (1880-85) where the notion of franchise is recast to denote not free persons but free lords (33:66-68). Writing to Norton, Ruskin mentions "true Liberty-(غ่) $\varepsilon v \theta \varepsilon \rho i ́ \alpha)$ " as under threat from a republicanism that had "uncorked 'Liberty' instead of 'Justice"” (Ruskin to Norton, 21 September 1869, in Correspondence, 173). As a political concept-freedom from subjection, and the corresponding concept of a free person-eleutheria is coeval with democracy in ancient Greece; Plato replaces the negative concept with sōphrosyne, self-control. In Rome, libertas had several meanings, including resistance to arbitrary power. With Christianity these concepts, unmoored from politics, combine the senses of freedom from sin and death with divine subjection. See Oxford Classical Dictionary, ed. Simon Hornblower and Antony Spawforth, 3rd ed. (Oxford: Oxford Univ. Press, 1999), s.v. "freedom in the ancient world."

${ }^{57}$ Conversely, Ruskin notes that in Dante Alighieri's Inferno, a section of hell is reserved for "those who cannot rightly govern themselves," and mentions freedom of thought, expression, and the press (27:411).

${ }^{58}$ See 16:407, 17:249, and 19:76. In Time and Tide, Ruskin reflects on the Aristotelian notion of inherent slavery, and develops a reading of The Tempest that condenses his other creaturely figures. He sets the free-spirited service of Shakespeare's Ariel, noble when fettered, against the slavery of Caliban, who experiences "cramps" when restrained and is shiftless when free (17:254-60).

${ }^{59}$ In "A Joy For Ever" (1880; earlier delivered as lectures on "The Political Economy of Art," 1857), Ruskin discusses government as taking on paternal (not simply judicial) authority to create a healthy polity through "discipline," "restraint," and "interference" (16:24-27). An addendum expands the point, noting that law per se abridges liberty (see 16:106). For Ruskin's paternalism, see Quennell, 244; Rosenberg, 119; and Sherburne, 74-75, 216-26.

${ }^{60}$ Both are from the Latin denoting what is customarily established, "in accordance with law" (The Oxford Latin Dictionary, ed. P. G. W. Glare [Oxford: Clarendon Press, 1996], s.v. "sollemnis."). In the Preface (1871) to Sesame and Lilies, Ruskin makes a similar allusion: "There is no solemnity so deep, to a rightly-thinking creature, as that of dawn" (18:37).

${ }^{61}$ For comments on the Guild of St. George, see Eagles, 34, 52-94 and Atwood, 151-75. Discussing liberty and equality as undesirable aims in Time and Tide, Ruskin notes of Americans that they "set their trust in liberty and in equality, of which I detest the one, and deny the possibility of the other" (17:432).

${ }^{62}$ On the negative character of this theory, see Quentin Skinner, Liberty before Liberalism (Cambridge: Cambridge Univ. Press, 1998); and Skinner, "A Third Concept of Liberty," Proceedings of the British Academy 117 (2002): 262-63. Contrast Philip Pettit, Republicanism: A Theory of Freedom and Government (Oxford: Clarendon Press, 1997), 51. Although the categories of negative and positive liberty were available prior to his work, all subsequent theories invoke Isaiah Berlin's "Two Concepts of Liberty" (1958) as their foremost exponent. See "Two Concepts of Liberty," in Liberty: Incorporating Four Essays on Liberty, ed. Henry Hardy (Oxford: Oxford Univ. Press, 2002), 166-217. 
${ }^{63}$ See Pettit, 27-35; Skinner, "Freedom as the Absence of Arbitrary Power," in Republicanism and Political Theory, ed. Cécile Laborde and John W. Maynor (Malden: Blackwell, 2008), 84-87; and Skinner, "Third Concept," 247-68, which surveys historical sources from the Digest of Roman law and medieval common-law texts through the Roman historians translated into English before the revival of English republicanism in the seventeenth century.

${ }^{64}$ Skinner, "Third Concept," 247.

${ }^{65}$ Skinner, "Third Concept," 263, 257. The historical thrust of Skinner’s recuperative project is to uncover "rival intepretations of liberty" suppressed by the ideologically dominant counter-revolutionary critique initiated by Hobbes and inherited, to an extent, by Mill ("Third Concept," 247).

${ }^{66}$ Hilton, 120-21, 124. Sherburne, 209-11 comments on Ruskin's ambivalence towards the French Revolution, about which he came to adopt a more urgent, Burkean stance. Edward Alexander argues that the events of 1848 compelled Ruskin to cement his vision of naturalized law and restraint. See Matthew Arnold, John Ruskin, and the Modern Temper (Columbus: Ohio State Univ. Press, 1973), 24-37, 49-50. In Fors Clavigera and elsewhere, Ruskin is overt on these matters: "I hate republicans," he notes, "as I do all other manner of fools" (28:547). Yet he often directs his ire at the French alone, who forget the thing (res) that a public (publica) should hold as its end, aiming rather for "Common-Illth" and "Public-Nothing" (27:122). Although he favors monarchical over republican arrangements, and laments the "license and insolence of modern republicanism" (33:430), Ruskin intimates throughout Fors Clavigera that the form of government is often unimportant, so long as there is wise and just rule (see 17:248-49, 27:17-18, 232-34).

${ }^{67}$ Compare 8:249 and 20:174.

${ }^{68}$ See Pettit, 55-56 and Skinner, "Freedom," 87-88. Sherburne notes that the rhetorical inversion of freedom and slavery was a "well-worn and ambiguous forensic device," to be found also in writers like Carlyle and Cobbett (220-22). For more on the Eyre case, Ruskin's endorsement of Carlyle's committee against Mill's, and slavery more broadly, see Anthony, 179-80; and John McCoubrey, "Turner's Slave Ship: Abolition, Ruskin, and Reception," Word \& Image 14 (1998): 319-53. Compare Catherine Gallagher, who surveys the rhetoric of freedom and slavery in critics of industrialism, opposing "alternative ideas of liberty" to those of the period's liberal political economists (The Industrial Reformation of English Fiction [Chicago: Univ. of Chicago Press, 1985], 4).

${ }^{69} \mathrm{In}$ a rich reading of Stones of Venice as a "drama of agency" turning on questions of freedom and determinism, individual agency and providence, Thomas notes how Ruskin points to architecture's "antagonism between individual expression and a sense of the agent's subscription to outlying norms and protocols," privileging forms that join the individual to the general (57). He points to Ruskin's tension in describing objects "constructed and determinable by more or less universal laws," when they also act as "staging points for a more individualized free expression" (51).

${ }^{70}$ Wordsworth, "Resolution and Independence," in Poems, 126, quoted, omitting punctuation, on 4:115. Carl Woodring is off the mark in suggesting that Ruskin sees a "false stability" in the clouds here ("On Liberty in the Poetry of Wordsworth," PMLA 70 [1955]: 1046). Still, his argument about Wordsworth's changing views of liberty expressed in terms of natural entities has parallels with mine (see Woodring, 1045-48).

${ }^{71}$ Ruskin elsewhere adverts to the figure of a well-governed river to press his broader critique of laissez-faire economics, suggesting, in the phrase of a note to Munera Pulveris, 
that "liberty is lost only when interference hinders, not when it helps" (17:289n2). See Sherburne, 168-70. Compare the conclusion of Verona, and its Rivers (1870): "both [Italy's] passions and her mountain streams are noble; but . . . her happiness depends, not on the Liberties, but the right Government of both" (19:448).

${ }^{72}$ Coleridge, Poetical Works, ed. J. C. C. Mays, 3 vol. (Princeton: Princeton Univ. Press, 2001), 1:463. Ruskin appears to cite the poem as it first appeared in the Morning Post in 1798 and in Sibylline Leaves (1817); only a corrected version, in 1802, contains the "Argument." For texts and discussion, see Poetical Works, 1:462-68, 2:585-93.

${ }^{73}$ Coleridge, 2:587-88.

${ }^{74}$ Compare Ruskin in Letter 54 of Fors Clavigera (1875), where he writes of those "visible powers of nature"-his parents - that he obeyed their "word, or lifted finger . . simply as a ship her helm" (28:350).

${ }^{75}$ Wordsworth, "Ode to Duty," in Poems, 107. James K. Chandler reads the poem as tacitly critiquing Coleridge's indiscipline and his enthusiasm for Kantian ethics: "acting according to one's own volition means invariable conformity to moral law" (Wordsworth's Second Nature: A Study of the Poetry and Politics [Chicago: Univ. of Chicago Press, 1984], 250). See also Jacob Risinger, "Wordsworth’s Imaginative Duty," Romanticism 14 (2008): 207-18.

${ }^{76}$ Coleridge, "Fancy in Nubibus," in Poetical Works, 1:943. Ruskin resisted this pathetic fallacy: "as far as I know clouds myself, they always look like clouds" (33:389).

${ }^{77}$ See Fitch; Michael Wheeler, ed., Ruskin and Environment: The Storm-Cloud of the Nineteenth Century (Manchester: Manchester Univ. Press, 1995); and Brian J. Day, "The Moral Intuition of Ruskin's 'Storm-Cloud," Studies in English Literature, 1500-1900 45 (2005): 917-33.

${ }^{78}$ Favret, 131. She also notes how weather was only understood as a global phenomenon in the late eighteenth century (126). Compare Bate, 20-21; Levinson, 636; and Jacobus, 25-26. 